\title{
The Hob proteins are novel and conserved lipid binding proteins at ER-PM contact sites
}

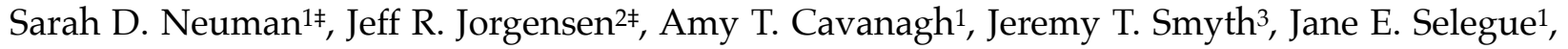
Scott D. Emr², Arash Bashirullah1*

${ }^{1}$ Division of Pharmaceutical Sciences, University of Wisconsin-Madison, Madison, WI, USA $53705-2222$.

2Weill Institute for Cell and Molecular Biology and Department of Molecular Biology and Genetics, Cornell University, Ithaca, NY 14853.

3Department of Anatomy, Physiology, and Genetics, F. Edward Hébert School of Medicine, Uniformed Services University of the Health Sciences, Bethesda, MD, 20814, USA.

‡ S.D.N. and J.R.J. contributed equally to this work

*bashirullah@wisc.edu; ORCID: 0000-0001-7150-1775

Keywords: ER-PM contact sites, phosphatidylinositols, S. cerevisiae, Drosophila, salivary gland, regulated exocytosis 


\begin{abstract}
Membrane contact sites are critical junctures for organelle signaling and communication. Endoplasmic reticulum-plasma membrane (ER-PM) contact sites were the first membrane contact sites to be described; however, the protein composition and molecular function of these sites is still emerging. Here, we leverage yeast and Drosophila model systems to uncover a novel role for the Hobbit/Hob proteins at ER-PM contact sites. We find that Hobbit localizes to ER-PM contact sites in both yeast cells and the Drosophila larval salivary glands, and this localization is mediated by an N-terminal ER membrane anchor and conserved C-terminal sequences. The Cterminus of Hobbit binds to plasma membrane phosphatidylinositols, and the distribution of these lipids is altered in hobbit mutant cells. Notably, the Hobbit protein is essential for viability in higher animals, providing one of the first examples of a membrane contact site-localized lipid binding protein that is required for development.
\end{abstract}




\section{INTRODUCTION}

Eukaryotic cells are defined by the presence of distinct and specialized membrane-bound organelles, and this subcellular compartmentalization enables a wide range of complex cellular functions. In recent years, the importance of organelle membrane contact sites (MCS) for cellular physiology has become increasingly apparent and appreciated; MCS are critical sites for signaling, metabolic channeling, lipid trafficking, organelle fission or fusion, and calcium homeostasis, among other functions (Prinz et al., 2020). MCS are ubiquitous; every type of eukaryotic cell contains them, and every organelle within a cell forms a functional contact site with at least one other organelle (Prinz et al., 2020; Shai et al., 2018; Valm et al., 2017). The endoplasmic reticulum (ER) in particular makes extensive contacts with other organelles, including the plasma membrane (PM), Golgi, mitochondria, peroxisomes, endosomes, lysosomes/vacuoles, and lipid droplets (Wu et al., 2018).

ER-plasma membrane (ER-PM) contact sites were the first MCS to be described. These contact sites were identified in electron microscopy (EM) images of muscle cells in the 1950s (Porter and Palade, 1957). ER-PM contact sites are particularly ubiquitous and prevalent in yeast, with nearly $40 \%$ of the PM in contact with the ER (Manford et al., 2012; Pichler et al., 2001; West et al., 2011). Yeast ER-PM contact sites are maintained by six or seven conserved tethering proteins: the tricalbins (Tcb1/2/3), two vesicle-associated membrane protein (VAMP)-associated proteins (VAPs; Scs2 and Scs22), the putative ion channel Ist2, and the more recently described Ice2 (Manford et al., 2012; Quon et al., 2018). Genetic deletion of six tethers (the tricalbins, VAPs, and Ist2; $\Delta$ tether strain) causes dramatic changes in ER morphology, with collapse of cortical ER contacts and redistribution of the ER into the cytosol (Manford et al., 2012). In yeast, ER-PM contact sites play critical roles in lipid trafficking and homeostasis, including phosphatidylinositol trafficking and turnover (Manford et al., 2012; Stefan et al., 2011), sterol trafficking and transfer (Schulz et al., 2009), and maintenance of proper lipid synthesis (Jorgensen et al., 2020; Omnus et al., 2016). However, surprisingly, ER-PM contact sites are not required for yeast viability under normal laboratory growth conditions (Manford et al., 2012).

ER-PM contact sites are also present in metazoans, but the abundance and morphology of these MCS varies widely by cell type (Saheki and De Camilli, 2017). Like yeast, ER-PM contacts in metazoans are maintained by tethering proteins, including the Extended Synaptotagmins (ESyts; orthologous to yeast tricalbins) (Giordano et al., 2013; Henne et al., 2015), VAPs (Murphy and Levine, 2016), and a number of other proteins that act as dynamic tethers in specific functional contexts or cell types (Eisenberg-Bord et al., 2016; Henne et al., 2015). The functions 
of ER-PM contact sites in metazoans are diverse but fall into two major categories: calcium homeostasis and non-vesicular lipid transfer.

Store-operated calcium entry (SOCE) is activated to replenish ER calcium stores when they have been depleted (Hogan and Rao, 2015). SOCE is primarily mediated by ER-localized STIM proteins and PM-localized Orai calcium channels, both of which were first discovered in RNAi screens conducted in Drosophila S2 cells (Feske et al., 2006; Liou et al., 2005; Roos et al., 2005; Vig et al., 2006; Zhang et al., 2006). SOCE is essential for development, as STIM and Orai knockouts are lethal in both mice and Drosophila (Baba et al., 2008; Cuttell et al., 2008; Gwack et al., 2008; Oh-hora et al., 2008; Pathak et al., 2017; Stiber et al., 2008). Several different lipid moieties undergo non-vesicular transfer at ER-PM contact sites, including sterols, glycerophospholipids, and phosphatidylinositols (Henne et al., 2015; Saheki and De Camilli, 2017). However, knockout or mutation of most characterized lipid transfer proteins does not result in animal lethality, suggesting either that lipid transfer is not essential for development or that functionally redundant transfer proteins can compensate for one another.

The Hobbit/Hob proteins are large (>2000 amino acid) proteins that are conserved throughout eukaryotes, but little is known about their molecular function. We identified hobbit in a genetic screen for Drosophila mutants that arrest development during metamorphosis with a small pupa phenotype, and found that hobbit function is required in professional secretory cells, including the insulin producing cells (IPCs) and larval salivary glands, for regulated exocytosis (Neuman and Bashirullah, 2018). Phenotypes have also been observed upon mutation of the plant orthologs of hobbit. Mutation of $A$. thaliana $S A B R E$ results in short roots with increased diameter and formation of ectopic root hairs; $S A B R E$ function is thought to be required for proper plant cell expansion and maintenance of planar cell polarity (Aeschbacher et al., 1995; Benfey et al., 1993; Pietra et al., 2015, 2013; Yu et al., 2012). Mutation of A. thaliana KIP, a putative paralog of $S A B R E$, causes defects in pollen tube growth (Procissi et al., 2003), as does mutation of Z. mays APT1 (Xu and Dooner, 2006). Finally, mutation of the SABRE ortholog in the moss P. patens causes stunted growth, defects in polarized growth, and failures in cell division (Cheng and Bezanilla, 2020). Although genetic screens in plants and insects have revealed phenotypic insights, the molecular function of hobbit and its orthologs has remained elusive.

Here we use both yeast and Drosophila model systems to examine the function of hobbit. We find that Hobbit localizes to ER-PM contact sites in both yeast and Drosophila salivary gland cells, and this localization is mediated by an N-terminal membrane anchor and conserved C-terminal sequences. Our data also shows that ER-PM localization is required for hobbit function. Notably, 
the C-terminal Apt1 domain of Hobbit binds to phosphatidylinositols, and the distribution of $\mathrm{PI}(4,5) \mathrm{P}_{2}$ is altered in hobbit mutant cells. Together, these results demonstrate that Hobbit is a novel protein that localizes to ER-PM contact sites and suggest that Hobbit may be a lipid transfer protein whose function is required for animal development. 
bioRxiv preprint doi: https://doi.org/10.1101/2021.03.02.433623; this version posted March 2, 2021. The copyright holder for this preprint (which was not certified by peer review) is the author/funder, who has granted bioRxiv a license to display the preprint in perpetuity. It is made available under aCC-BY 4.0 International license.

\section{RESULTS}

\section{The $S$. cerevisiae orthologs of hobbit localize to ER-PM contact sites}

The S. cerevisiae genome contains two predicted orthologs of hobbit: FMP27 and YPR117W. To begin to characterize these proteins in yeast, we generated GFP-tagged versions of both proteins under control of their endogenous promoters and examined where they localized within the cell. Both proteins localized in cortical patches or puncta (Fig. 1A, S1A), like other proteins that localize to ER-PM contact sites (Manford et al., 2012). We focused primarily on Fmp27-GFP because Ypr117w-GFP was expressed at barely detectable levels (Fig. S1A). We found that the Fmp27-GFP cortical puncta co-localized with the pan-ER marker RFP-HDEL and with the ERPM tether Tcb3-mCherry (Fig. 1A-B) (Manford et al., 2012), providing further evidence that Fmp27 localizes to ER-PM contact sites. Some proteins that are enriched at ER-PM contact sites are anchored to the plasma membrane, while others are anchored to the ER (Hogan and Rao, 2015). To distinguish between these possibilities, we examined the localization of Fmp27-GFP in a strain that knocks out six ER-PM tether proteins (Atether) (Manford et al., 2012). Fmp27-GFP was no longer present in cortical puncta in the $\Delta$ tether background and instead localized to perinuclear and internal structures that co-localized with RFP-HDEL (Fig. 1C), indicating that

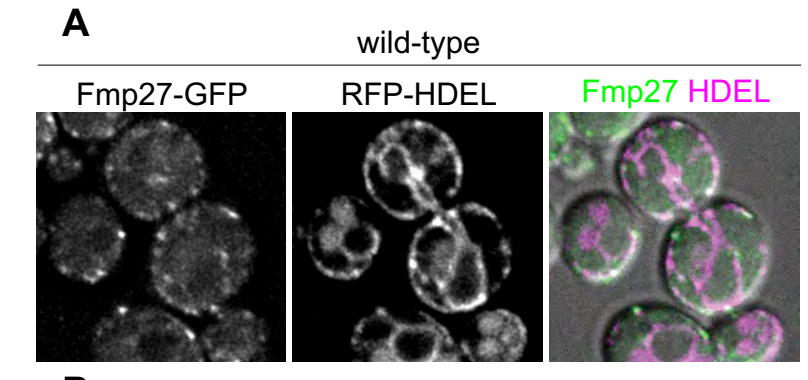

wild-type

B

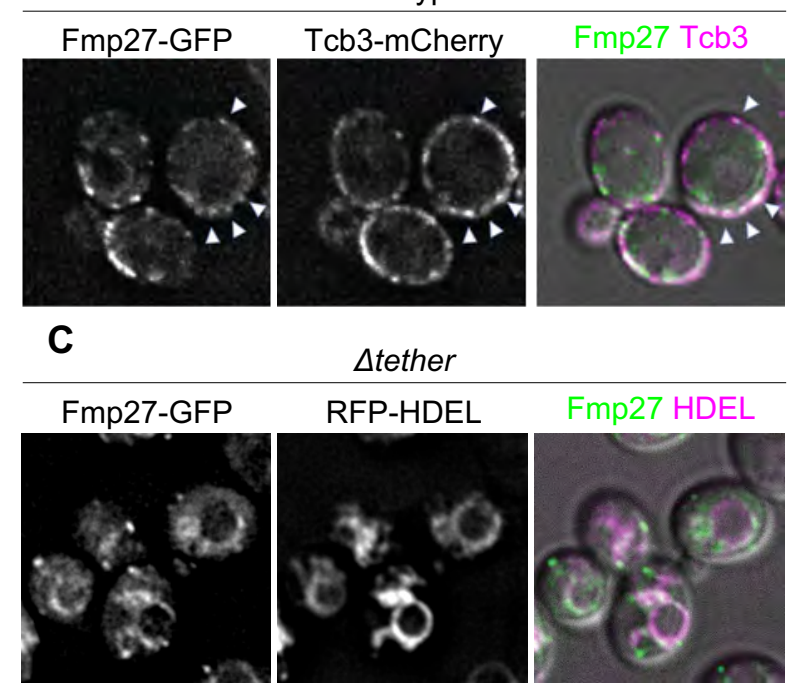

wild-type
Figure 1. Fmp27 localizes to ER-PM contact sites. (A) Live-cell imaging of endogenously tagged Fmp27-GFP (green) shows that Fmp27 is enriched in puncta at the cell cortex that co-localize with RFP-HDEL (magenta), a panER marker. RFP-HDEL is expressed from a plasmid. (B) Live-cell imaging of Fmp27-GFP (green) with the ER-PM tether Tcb3-mCherry (magenta) confirms that Fmp27 is enriched at ER-PM contact sites. (C) Live-cell imaging of endogenously tagged Fmp27-GFP (green) in the $\Delta$ tether background with RFP-HDEL (magenta) shows that Fmp27 localizes to collapsed ER upon loss of ER-PM tethers. RFPHDEL is expressed from a plasmid. 
Fmp27 localizes to collapsed ER in the $\Delta$ tether mutant and confirming that Fmp27 is an ERlocalized protein. FMP27 (Found in Mitochondrial Proteome) got its name from mitochondrial proteome analysis (Reinders et al., 2006), raising the possibility that this protein may also be present in mitochondria. We therefore examined the localization of FMP27-GFP with the mitochondrial marker Su9-DsRED but did not observe any co-localization (Fig. S1B), suggesting that Fmp27 may have been a contaminant in the mitochondrial proteome study. Overall, these results demonstrate that Fmp27 is an ER-localized protein enriched at ER-PM contact sites in yeast.

\section{Yeast hobbit localizes to the ER via an N-terminal membrane anchor}

We next wanted to determine how Fmp27 localizes to the ER. Bioinformatic transmembrane prediction programs suggest that there may be a transmembrane domain at the N-terminus of the protein. Consistent with this prediction, deletion of the first 192 highly conserved amino acids at the N-terminus of the protein (GFP-Fmp27 $\Delta$ N192) abolished ER localization and caused the truncated protein to localize to the cytosol (Fig. 2A, S1C), indicating that Fmp27 is anchored to the ER by a transmembrane domain or hairpin at the N-terminus. We next analyzed the

\section{A}
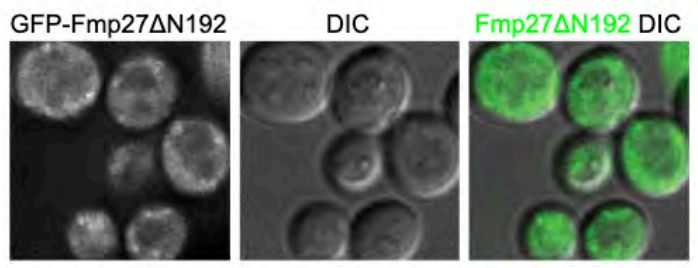

B

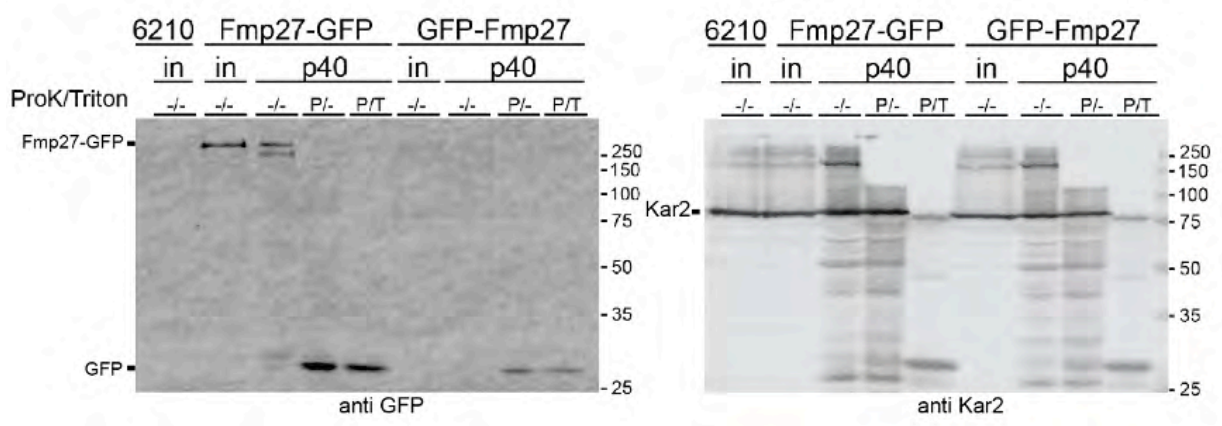

Figure 2. Fmp27 localizes to the ER via an N-terminal membrane anchor with the C-terminus facing the cytosol.

(A) Live-cell imaging of $\mathrm{N}$-terminally truncated Fmp27 (GFP-Fmp27DN192; green) shows that the truncated protein localizes to the cytosol. N-terminal truncation was made at the endogenous FMP27 locus but expressed using the YPQ1 promoter. (B) (Left) a-GFP western blot showing Fmp27-GFP and GFP-Fmp27 from cell lysate or the p40 fraction (microsomes). The p40 fraction was either mock-treated, treated with $0.12 \mu \mathrm{g} / \mathrm{mL}$ proteinase $\mathrm{K}$, or $0.12 \mu \mathrm{g} / \mathrm{mL}$ proteinase $\mathrm{K}$ and $1 \%$ Triton X-100. The appearance of a free GFP band in the proteinase K-treated Fmp27-GFP p40 fraction shows that the C-terminus of Fmp27 faces the cytosol. (Right) a-Kar2 (ER lumen protein) western blot from the same samples in the left panel. "in" represents input, "P" represents that proteinase K was added, "T" represents that Triton X-100 was added. 
membrane topology of Fmp27. We isolated microsomes from cells expressing either Fmp27-GFP or GFP-Fmp27 and performed protease protection assays. In these assays, the luminal domain of Fmp27 should be protected from proteinase K, and GFP, which is a highly stable and tightly folded protein, should run as a free band on a gel if exposed to the cytosol. Note that GFP is resistant to degradation by proteinase $\mathrm{K}$ under these experimental conditions. GFP-Fmp27 was barely detectable in its full-length form (Fig. 2B), suggesting that N-terminal GFP tagging interferes with membrane insertion of the protein and may cause it to be degraded. In contrast, Fmp27-GFP was degraded after proteinase $\mathrm{K}$ treatment, as evidenced by the appearance of a free GFP band on the gel (Fig. 2B). The ER luminal protein Kar2 (Rose et al., 1989) was used as a control to show that the ER lumen is protected from proteinase $\mathrm{K}$ under these conditions (Fig. 2B). These results demonstrate that Fmp27 is anchored to the ER via an N-terminal transmembrane domain or hairpin and the C-terminus of Fmp27 faces the cytosol.

\section{Fmp27 does not function as an ER-PM tether in yeast}

Several ER-PM tethering proteins have been identified in yeast, and deletion of six or seven of them is required to significantly reduce the formation of these contact sites (Manford et al., 2012; Quon et al., 2018). However, even upon deletion of seven tethers, cortical ER is still occasionally observed, which could be due to incidental contact or to the function of unidentified tethers (Quon et al., 2018). The topology of Fmp27, with an N-terminal membrane anchor and a large cytosolic domain, coupled with its localization to ER-PM contact sites, is consistent with a potential function as an ER-PM tether. To examine this possibility, we first generated knockouts

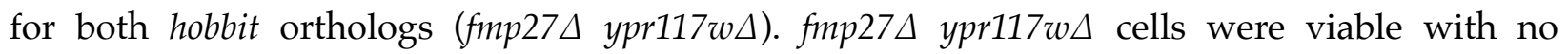
obvious growth phenotypes on complete media. Imaging of RFP-HDEL did not reveal any

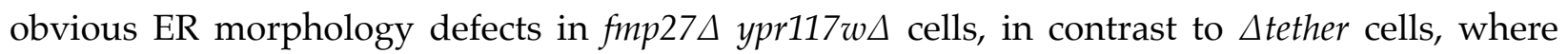
nearly all cortical ER is lost (Fig. 3A). We also used thin-section transmission electron

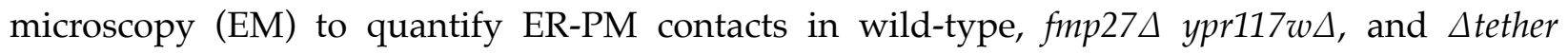
fmp27 ypr117w $\Delta$ (8 knockout) mutant cells. No significant differences were observed in the ratio of cortical ER/total PM between wild-type and fmp27 ypr117w $\Delta$ or between $\Delta$ tether and

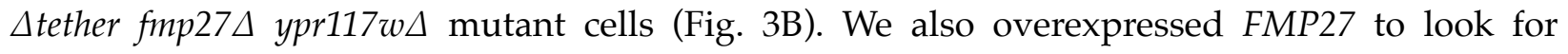
increased ER-PM contacts; however, we observed a slight reduction in the cortical ER/PM ratio in FMP27-overexpressing cells (Fig. 3B). Finally, we tested if overexpression of FMP27 could rescue the loss of cortical ER in $\Delta$ tether cells. We used fluorescence microscopy with RFP-HDEL to examine ER morphology and did not see a rescue of ER-PM contact site formation in $\Delta$ tether cells overexpressing FMP27 (Fig. 3C). Taken together, these results demonstrate that Fmp27 localizes to ER-PM contact sites but does not appear to function as a tether. 
bioRxiv preprint doi: https://doi.org/10.1101/2021.03.02.433623; this version posted March 2, 2021. The copyright holder for this preprint (which was not certified by peer review) is the author/funder, who has granted bioRxiv a license to display the preprint in perpetuity. It is made available under aCC-BY 4.0 International license.

A
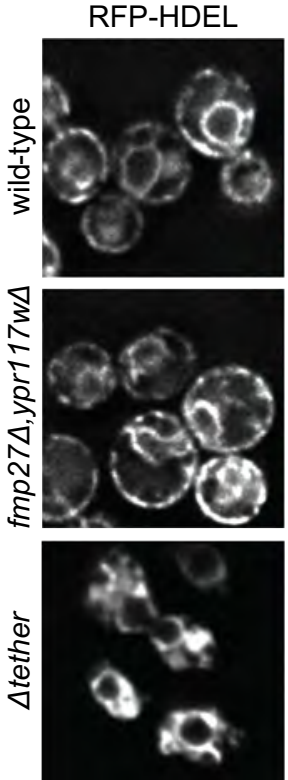

HDEL DIC
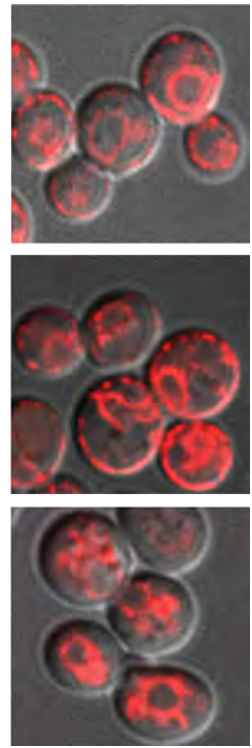

B

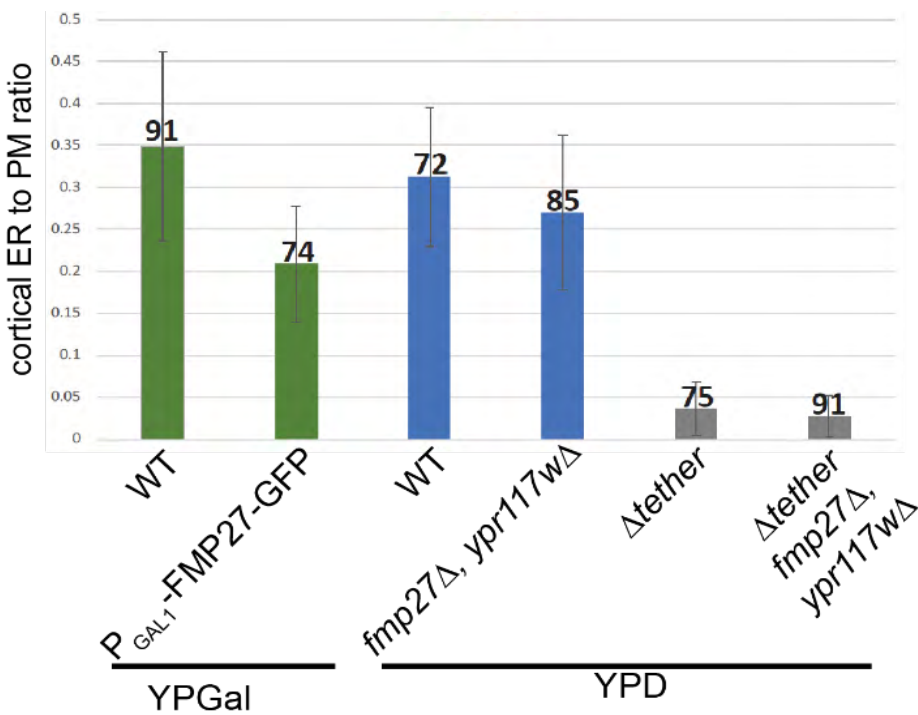

C
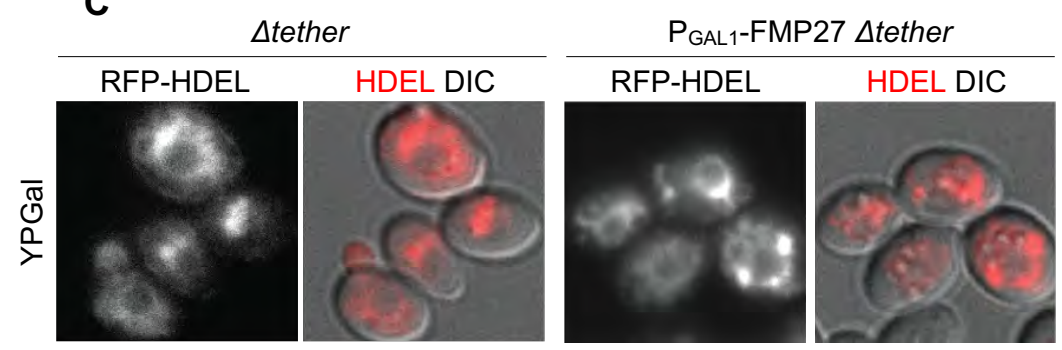

Figure 3. Fmp27 does not function as an ER-PM tether. (A) Live-cell imaging of RFP-HDEL (red) in control, fmp27 $\Delta$ ypr $117 w \Delta$, and $\Delta$ tether cells shows that ER morphology is unaffected upon loss of both copies of the yeast ortholog of hobbit, in contrast to $\Delta$ tether cells, where nearly all cortical ER is lost. (B) Quantification of the ratio of cortical ER/total

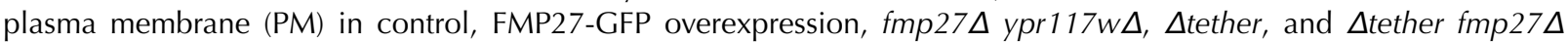
ypr117w $\Delta$ shows that overexpression of Fmp27 does not increase the number of cortical ER contacts (green bars), nor does loss of both Fmp27 and Ypr117w decrease the number of cortical ER contacts in a wild-type (blue bars) or $\Delta$ tether background (gray bars). Cells were grown on YPGal media to drive Fmp27 overexpression; otherwise, cells were grown on standard YPD media. Graphs show mean +/- S.D. The number atop each bar represents the number of cells for which the cortical-ER/PM ratio was measured. (C) Live-cell imaging of RFP-HDEL (red) in $\Delta$ tether (left) and $\Delta$ tether cells overexpressing Fmp27 (right) shows that overexpression of Fmp27 does not rescue cortical ER contacts in the $\Delta$ tether background. Fmp27 is expressed under its endogenous promoter in the left panels, and under the GAL1 promoter in right panels. Cells were collected from mid-log cultures grown in YPGal media to drive Fmp27 overexpression.

\section{Membrane topology of hobbit is conserved in Drosophila}

Since we did not observe any obvious phenotypes in yeast that provide clues to the function of hobbit at ER-PM contact sites, we turned to Drosophila, where mutation of hobbit results in a dramatic reduction in animal body size, lethality during metamorphosis, and defects in regulated exocytosis in multiple cell types, including the insulin producing cells and the larval 
bioRxiv preprint doi: https://doi.org/10.1101/2021.03.02.433623; this version posted March 2, 2021. The copyright holder for this preprint (which was not certified by peer review) is the author/funder, who has granted bioRxiv a license to display the preprint in perpetuity. It is made available under aCC-BY 4.0 International license.

salivary glands (Neuman and Bashirullah, 2018). We first wanted to determine if the ER membrane localization of Hobbit was conserved in flies. Our previous work demonstrated that Hobbit localizes to the ER (Neuman and Bashirullah, 2018). High resolution confocal microscopy enabled us to determine that Hobbit is present on the ER membrane in the larval salivary glands; we observed Hobbit-GFP enriched around the ER luminal marker KDEL-RFP but non-overlapping with cytoplasmic mTagBFP2 (Fig. 4A). Additionally, Kyte-Doolittle hydrophobicity analysis (Kyte and Doolittle, 1982) shows a short, highly hydrophobic region at

A

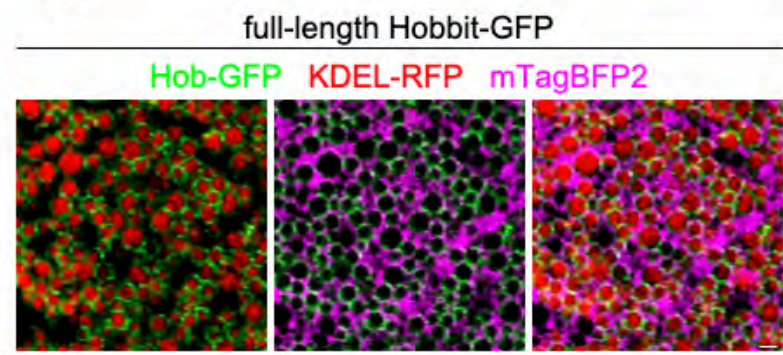

B

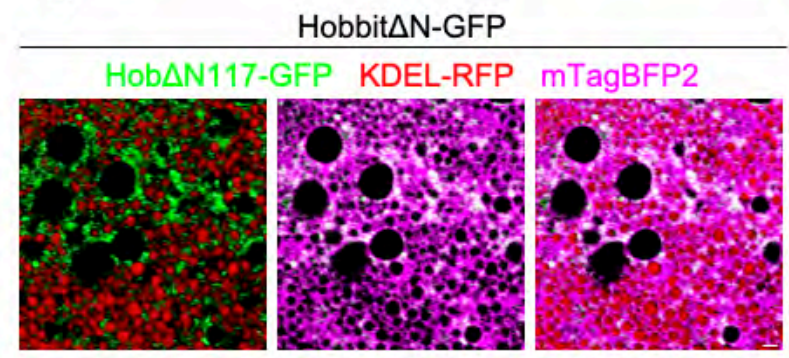

C

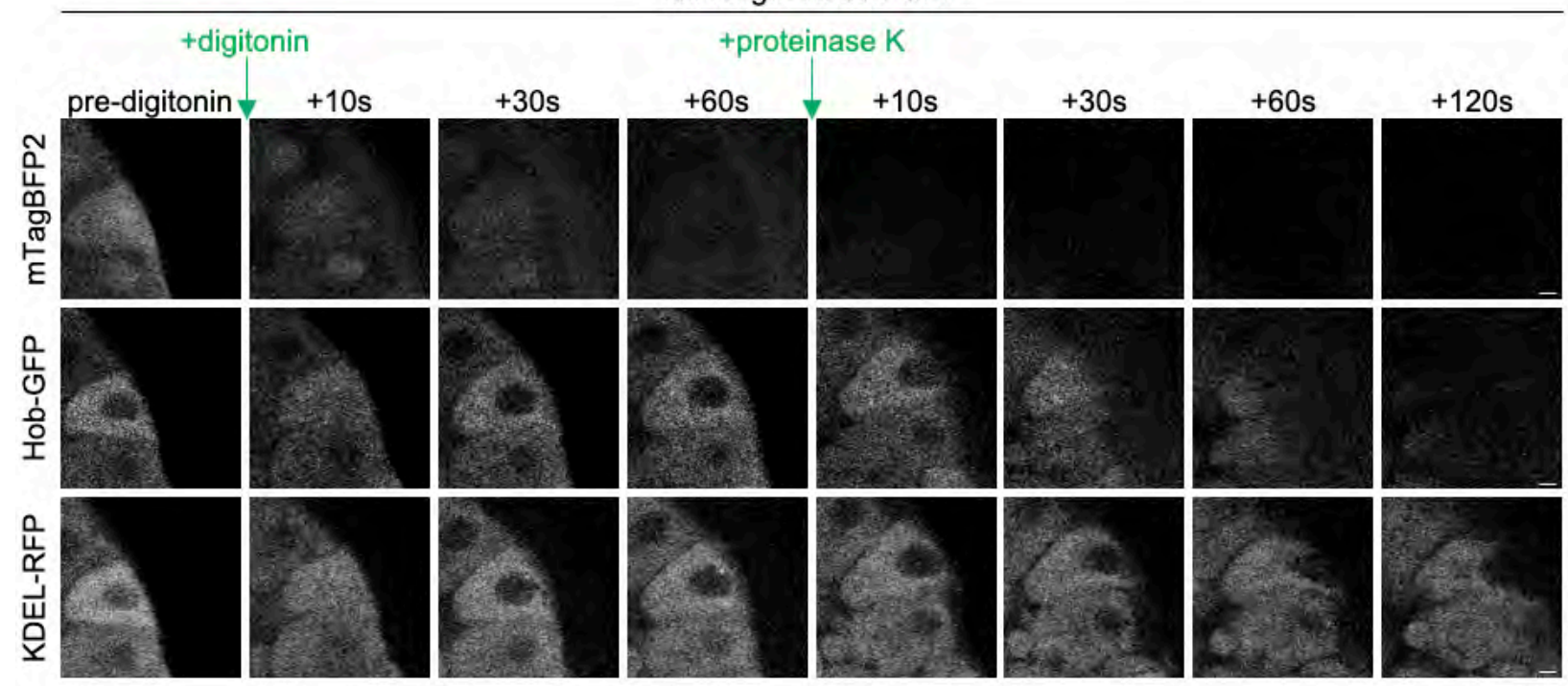

Figure 4. ER membrane localization and topology of Hobbit are conserved in Drosophila. (A) Live-cell imaging of full-length Hobbit-GFP (green), the ER lumen marker KDEL-RFP (red), and cytosolic mTagBFP2 (magenta) in the Drosophila larval salivary glands at the onset of metamorphosis ( $0 \mathrm{~h}$ after puparium formation, PF) shows that HobbitGFP localizes to the ER membrane. Full genotype: UAS-KDEL-RFP/+; Sgs3>hob-GFP/UAS-mTagBFP2. (B) Live-cell imaging of N-terminally truncated Hobbit $\triangle \mathrm{N} 117-\mathrm{GFP}$ (green), the ER lumen marker KDEL-RFP (red), and cytosolic mTagBFP2 (magenta) at $0 \mathrm{~h}$ PF shows that Hobbit $\triangle \mathrm{N} 117-\mathrm{GFP}$ localizes to the cytosol. Full genotype: UAS-KDEL-RFP/ +; Sgs3>hob $\triangle$ N117-GFP/UAS-mTagBFP2. Images in (A) and (B) show a single slice from a z-stack comprising three optical sections at a $0.28 \mu \mathrm{m}$ step size. (C) Imaging-based protease protection assay shows that the C-terminus of Drosophila Hobbit faces the cytosol. Cytosolic mTagBFP2 (top) rapidly diffuses out of the cells after permeabilization with digitonin, while Hobbit-GFP (middle) and KDEL-RFP (bottom) are unaffected. Hobbit-GFP (tagged at the Cterminus) is degraded after subsequent addition of proteinase K, while KDEL-RFP is unaffected. Note that the cells flatten after addition of proteinase K. Experiment was conducted using $0 \mathrm{~h}$ PF glands. Full genotype: UAS-KDEL-RFP/+; Sgs3>hob-GFP/UAS-mTagBFP2. Scale bars in (A, B): $1 \mu \mathrm{m} ;(\mathrm{C}): 10 \mu \mathrm{m}$. 
the N-terminus of the Hobbit protein (Fig. S2A), consistent with a possible transmembrane domain. Like yeast, deletion of a highly conserved N-terminal region resulted in the loss of ER localization, as Hob $\triangle$ N117-GFP co-localized with cytoplasmic mTagBFP2 (Fig. 4B, Fig. S2B). Importantly, ER localization is critical for hobbit function, as ubiquitous overexpression of hob $\triangle N 117-G F P$ did not rescue the small body size or lethality of hobbit mutant animals (Fig. 6C). In contrast, we have previously reported that ubiquitous overexpression of full-length hobbitGFP inserted at the same genomic locus as hob $\triangle N 117-G F P$ fully rescues both body size and lethality in hobbit mutant animals (Neuman and Bashirullah, 2018). Our next goal was to determine if fly Hobbit had the same membrane topology as yeast Fmp27, and we conducted an imaging-based protease protection assay to analyze the topology. Addition of the selective detergent digitonin, which permeabilizes the plasma membrane but not intracellular membranes (Lorenz et al., 2006), resulted in the release of cytoplasmic mTagBFP2, while HobbitGFP and KDEL-RFP were unaffected (Fig. 4C, Movie 1). This further confirms that Hobbit is anchored to the ER membrane. Subsequent addition of proteinase $\mathrm{K}$ resulted in the progressive loss of Hobbit-GFP signal, while KDEL-RFP was unaffected (Fig. 4C), confirming that the Cterminus of fly Hobbit faces the cytosol.

\section{Hobbit localizes to ER-PM contact sites in Drosophila cells}

Fmp27 is highly enriched at ER-PM contact sites; therefore, we wanted to determine if Hobbit was present at these sites in Drosophila cells. The protein composition of ER-PM contact sites is poorly understood in Drosophila; therefore, we developed a new marker for these sites based on the structure of the Stim protein. Drosophila Stim and its human ortholog STIM1 are wellcharacterized ER membrane proteins that localize to ER-PM contact sites when ER calcium stores are depleted (Hogan and Rao, 2015). To generate a Stim reagent that constitutively labels ER-PM junctions, we changed D155 and D157 of Drosophila Stim (orthologous to D76 and D78 in human STIM1) to A (StimDDAA-GFP). These amino acids are required for calcium binding within the EF hand domain of Stim, and mutation of these sites locks Stim in an extended conformation that enables it to interact with Orai calcium influx channels specifically at ER-PM contact sites (Liou et al., 2005; Lunz et al., 2019; Zhang et al., 2005). Accordingly, we find that StimDDAA-GFP localized in puncta that are present at the plasma membrane in larval salivary gland cells (Fig. 5A), consistent with the expected pattern and localization of ER-PM contact sites. Importantly, full-length Hobbit-mCherry strongly co-localized with StimDDAA-GFP puncta, indicating that fly Hobbit is enriched at ER-PM contact sites (Fig. 5B). Genetic rescue experiments confirmed that the hobbit-mCherry transgene produces functional protein (Fig. 6C). Additionally, StimDDAA-GFP appeared to localize normally in hobbit mutant cells (Fig. 5A), 
bioRxiv preprint doi: https://doi.org/10.1101/2021.03.02.433623; this version posted March 2, 2021. The copyright holder for this preprint (which was not certified by peer review) is the author/funder, who has granted bioRxiv a license to display the preprint in perpetuity. It is made available under aCC-BY 4.0 International license.

A

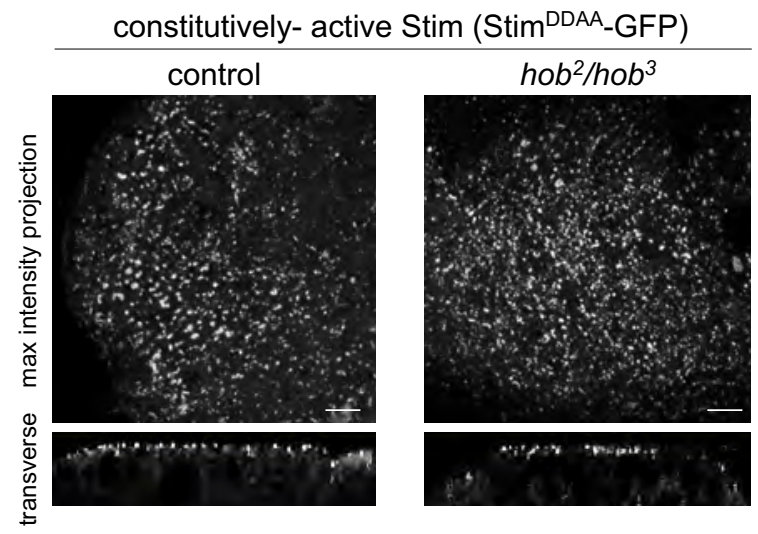

B full-length Hobbit-mCherry

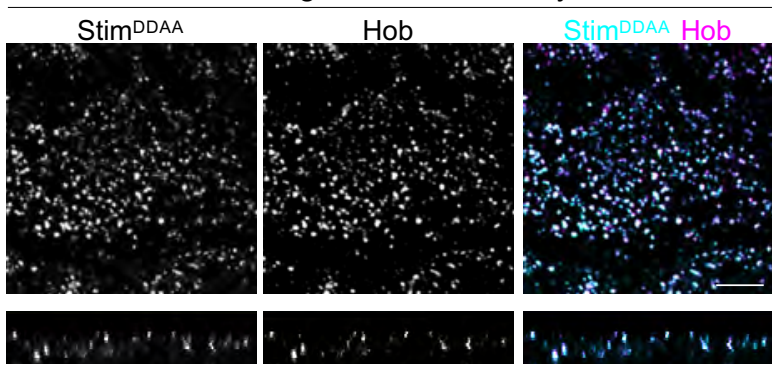

Figure 5: The C-terminus of Hobbit is required for localization to ER-PM contact sites. (A) Live-cell imaging of constitutively-active Stim (StimDDAA-GFP) in control and hobbit mutant salivary gland cells at the onset of metamorphosis ( $0 \mathrm{~h}$ after puparium formation, PF) shows that this protein localizes to puncta at the plasma membrane. Top images show a maximum intensity projection of 20 optical slices from a z-stack comprising 71 total slices (control) or 57 total slices (hobbit mutant) at a $0.36 \mu \mathrm{m}$ step size. Bottom images show a transverse section from the z-stacks shown above. Full genotypes- control: UAS-StimDDAA-GFP/+; SgS3>/+ and hobbit mutant: UAS-StimDDAA-GFP/+; hob ${ }^{2}$, Sgs 3>/hob ${ }^{3}$. (B) Live-cell imaging of constitutively-active Stim (StimDDAA-GFP, cyan) and full-length Hobbit (Hobbit-mCherry, magenta) in wandering L3 (wL3) salivary glands shows that Hobbit and constitutively-active Stim co-localize at ER-PM contact sites. Top images show a maximum intensity projection of 10 optical slices from a z-stack comprising 31 total slices at a $0.36 \mu \mathrm{m}$ step size. Bottom images show a transverse section from the $z$ stacks shown above. Full genotype: UAS-StimDDAA GFP/+; Sgs3>hob-mCherry/+. (C) Live-cell imaging of constitutively-active Stim (StimDDAA-GFP, cyan) and Cterminally truncated Hobbit (Hobbit $\triangle \mathrm{C} 82$-mCherry, magenta) in wandering L3 ( $w L 3)$ salivary glands shows that Hobbit $\triangle \mathrm{C} 82$ no longer localizes to ER-PM contact sites. Top images show a maximum intensity projection of 10 optical slices from a z-stack comprising 31 total slices at a $0.35 \mu \mathrm{m}$ step size. Bottom images show a transverse section from the $z-$ stacks shown above. Full genotype: UAS-Stim $D D A A_{-}$ GFP/+; Sgs3>hob $\Delta$ C82-mCherry/t. Scale bars: $5 \mu \mathrm{m}$.

indicating that ER-PM contact sites still form in the absence of hobbit. Taken together, these results demonstrate that Hobbit localization to ER-PM contact sites is conserved between yeast and flies.

\section{The C-terminus of Hobbit is required for ER-PM localization}

We have previously reported five mutant alleles of hobbit; all are nonsense mutations scattered throughout the 2300 amino acid protein (Neuman and Bashirullah, 2018) (Fig. S3A). Notably, one of these mutations, $h o b^{5}$, is only 82 amino acids away from the C-terminus of the protein, and this mutant allele is phenotypically indistinguishable from other nonsense mutations located much closer to the N-terminus, with a small body size, lethality during metamorphosis, and cell-autonomous defects in regulated exocytosis in the larval salivary glands (Fig. 6 A-B). 
bioRxiv preprint doi: https://doi.org/10.1101/2021.03.02.433623; this version posted March 2, 2021. The copyright holder for this preprint (which was not certified by peer review) is the author/funder, who has granted bioRxiv a license to display the preprint in perpetuity. It is made available under aCC-BY 4.0 International license.

A

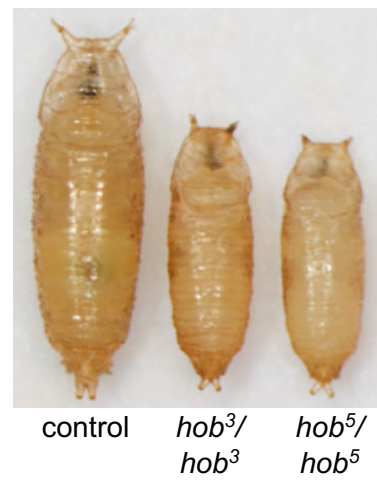

B
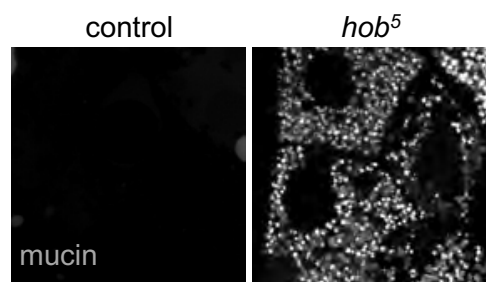

hob $\triangle C 82$ rescue
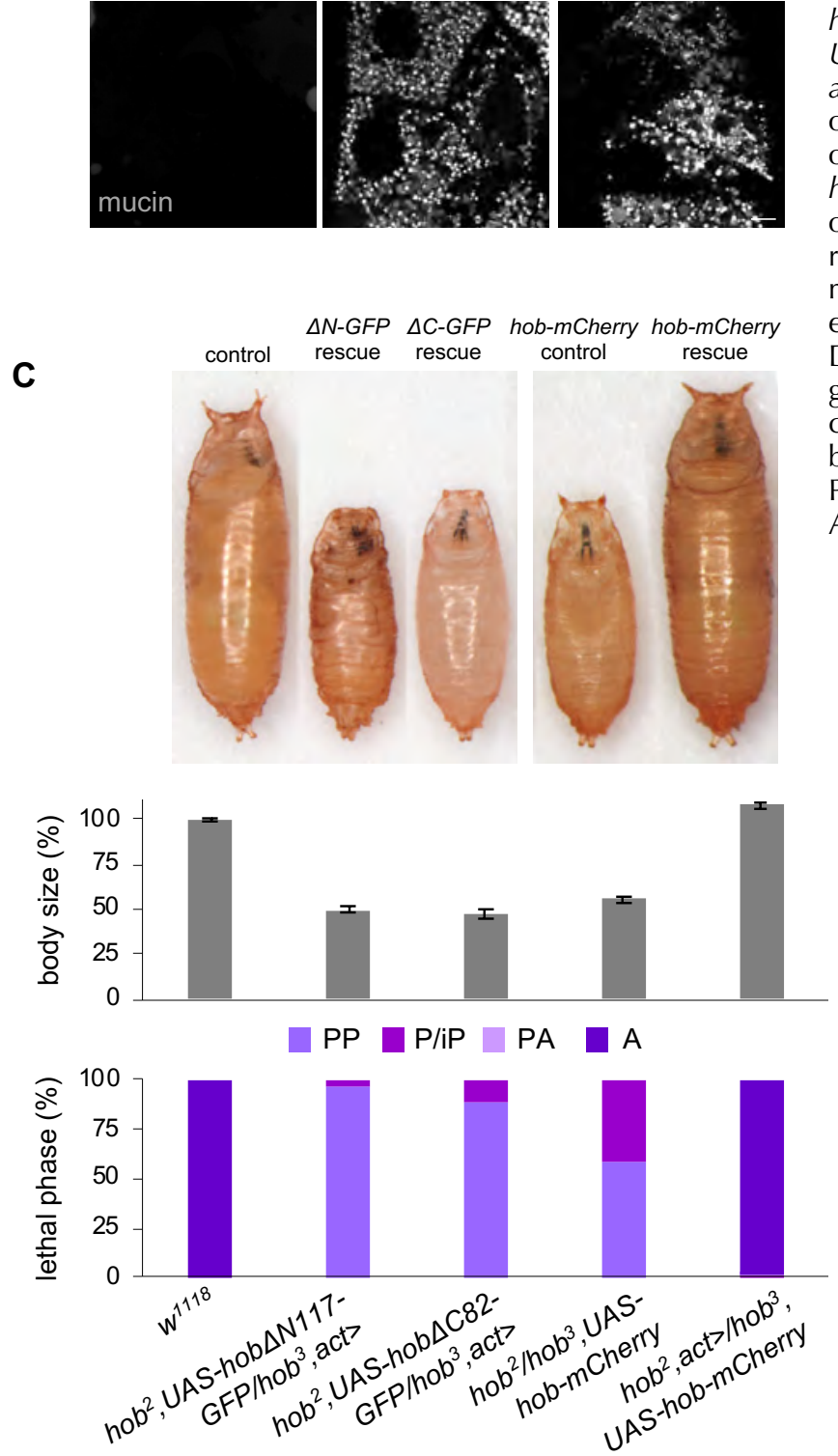

Figure 6. ER-PM localization is required for hobbit function. (A) Images of control ( $\left.w^{1118}\right)$, homozygous $h o b^{3}$, and homozygous hob $b^{5}$ upae shows that hob mutant animals display the same small body size as $h b^{3}$ mutant animals. (B) Live-cell imaging of mucins in control, homozygous hob ${ }^{5}$, and hob $\triangle C 82$ rescue salivary glands dissected from prepupal animals shows that mucins are secreted in controls but not in $h o b^{5}$ or hob $\triangle C 82$ rescue animals. Full genotypes- control: Sgs3-GFP/+. hob5: Sgs3-GFP/+; hob $5 / h^{2} b^{5}$. hob $\Delta C 82$ rescue: Sgs3-GFP/+; hob ${ }^{2}$, UAS-hob $\triangle$ C82-mCherry; $h^{3} b^{3}$, act>. (C) Body size quantification and lethal phase analysis for control ( $\left.w^{1118}\right)$, hob $\Delta$ N117-GFP rescue (hob ${ }^{2}$, UAS-hob $\Delta$ N117-GFP/hob ${ }^{3}$, act $>$ ), hob $\triangle$ C82-GFP rescue (hob ${ }^{2}$, UAS-hob $\triangle$ C82-GFP/ hob ${ }^{3}$, act $)$ ), hob-mCherry rescue control (hob h $^{2} / h_{0} b^{3}$, UAS-hob-mCherry), and hob-mCherry rescue (hob ${ }^{2}$, act $>/ h^{2} b^{3}$, UAS-hob-mCherry) shows that ubiquitous overexpression of neither $\mathrm{N}$ - nor C-terminal truncation of Hobbit rescues the small body size or lethality of hobbit mutant animals. In contrast, ubiquitous overexpression of full-length Hobbit-mCherry fully rescues the small body size and lethality of hobbit mutant animals. Body size quantified by pupa volume expressed as a percentage relative to control $(100 \%)$. Data shown as mean +/- S.E.M. $n=100$ animals per genotype. Note that the three pupae on the left were captured in a different image from the two on the right; both were imaged at the same magnification. PP: Prepupa; P/iP: Pupa/incomplete Pupa; PA: Pharate Adult; A: Adult. Scale bar in (B): $10 \mu \mathrm{m}$. 
These results suggest that critical functional elements are likely encoded in the final 82 amino acids of the Hobbit protein. C-terminal protein sequences are required for enrichment of other proteins at ER-PM contact sites (Giordano et al., 2013); therefore, we hypothesized that the Cterminal 82 amino acids may be required for Hobbit enrichment at ER-PM contact sites. To test this idea, we generated both GFP- and mCherry-tagged overexpression constructs that delete the final 82 amino acids of the Hobbit protein (hob $\triangle$ C82-GFP and hob $\triangle$ C82-mCherry). These truncated proteins still localized to the ER membrane and topology was unaffected (Fig. S3B-C, Movie 2). However, strikingly, Hob $\triangle$ C82-mCherry did not co-localize with StimDDAA_GFP (Fig. 5C), indicating that ER-PM contact site enrichment was lost upon deletion of the C-terminus of Hobbit. Additionally, ubiquitous overexpression of $\mathrm{Hob} \Delta \mathrm{C} 82$ did not rescue the small body size or lethality of hobbit mutant animals (Fig. 6C), nor did it rescue regulated exocytosis defects in the larval salivary glands (Fig. 6B). We also examined the effect of Fmp27 truncation in yeast cells. Like we observed with fly hobbit, deletion of the C-terminus of Fmp27 strongly reduced cortical ER-PM localization (Fig. S4). Overall, these results demonstrate that ER-PM localization is required for hobbit function.

\section{The C-terminal Apt1 domain of Hobbit binds to plasma membrane phosphatidylinositols}

Sequence analysis using the protein domain database Pfam (Mistry et al., 2021) predicts that the C-terminus of Hobbit contains an Apt1 domain, a protein domain that is highly conserved but appears to only be present in Hobbit and its orthologs. Primary sequence analysis of yeast Atg2, Vps13, and human VPS13A indicates that these proteins also contain an Apt1 domain (Kaminska et al., 2016; Kolakowski et al., 2020; Rzepnikowska et al., 2017); however, the presence of this domain is not predicted in these proteins by Pfam, perhaps because the primary sequence diverges from the Hobbit Apt1 domain. The Apt1 domains of Atg2, Vps13, and VPS13A bind to phosphatidylinositols (Kaminska et al., 2016; Kolakowski et al., 2020; Rzepnikowska et al., 2017), raising the possibility that Hobbit may also bind to these lipids. To test this hypothesis, we expressed recombinant Hobbit Apt1 domain in E. coli, purified it, and tested it for binding on membrane lipid strips. Strikingly, full-length Hobbit Apt1 bound to phosphatidylinositol (PI), PI(4)P, $\mathrm{PI}(4,5) \mathrm{P}_{2}$, and $\mathrm{PI}(3,4,5) \mathrm{P}_{3}$, while Apt1 lacking the C-terminal 82 amino acids (Apt1 $\Delta$ C82) did not bind to any of these lipids (Fig. 7A). These lipid moieties are known to be enriched at the plasma membrane (Balla, 2013), suggesting that the ER-PM localization of Hobbit may be mediated by binding to plasma membrane phosphatidylinositols. We also examined the subcellular distribution of one of these lipids, PI $(4,5) \mathrm{P}_{2}$, in control and hobbit mutant cells using the fluorescently-tagged binding reporter PLCSPH-GFP (Verstreken et al., 2009). As expected, PLC 8 PH-GFP was strongly enriched at the plasma membrane in both 
bioRxiv preprint doi: https://doi.org/10.1101/2021.03.02.433623; this version posted March 2, 2021. The copyright holder for this preprint (which was not certified by peer review) is the author/funder, who has granted bioRxiv a license to display the preprint in perpetuity. It is made available under aCC-BY 4.0 International license.

control and hobbit mutant cells; however, PLCऽPH-GFP also accumulated in large intracellular compartments in hobbit mutant cells (Fig. 7B), suggesting that hobbit plays a functional role in regulating the subcellular distribution of $\mathrm{PI}(4,5) \mathrm{P}_{2}$.

A

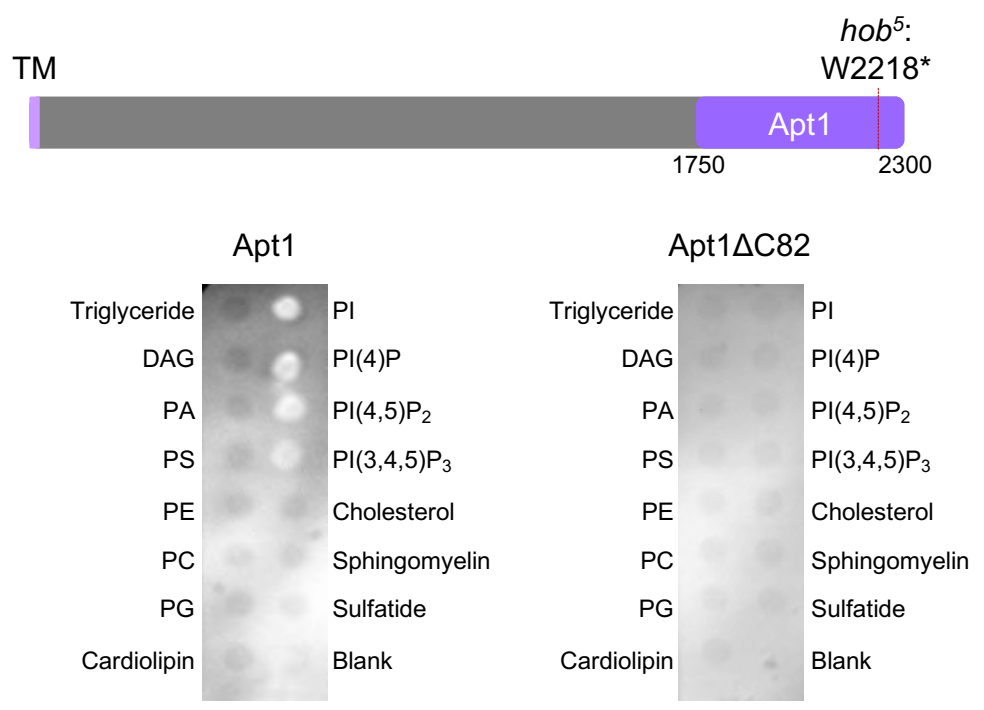

B
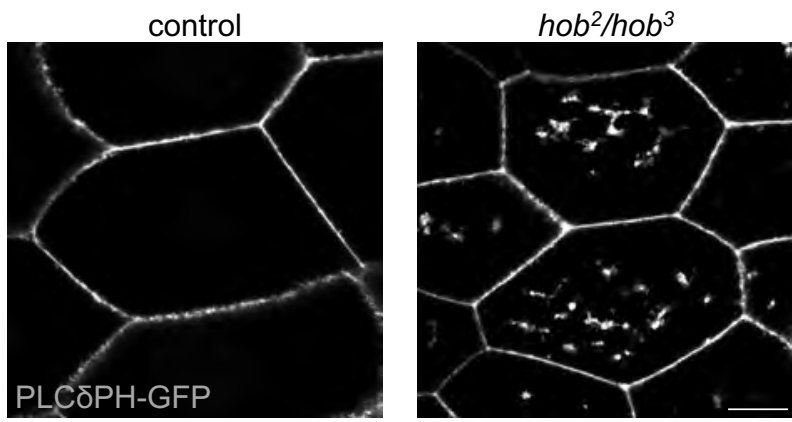

Figure 7: Hobbit binds to phosphatidylinositols and affects PI(4,5) $\mathbf{P}_{2}$ distribution. (A) Top: schematic depicting the Apt1 domain of Hobbit and the location of the $h o b^{5}$ nonsense mutation. Note that Pfam annotates the Apt1 domain as amino acids 1774-2239, but we included extra upstream and downstream sequence to ensure proper folding of the domain. Bottom: Lipid blot binding analysis shows that full-length Apt1 binds to phosphatidylinositol (PI), PI(4)P, $\mathrm{PI}(4,5) \mathrm{P}_{2}$, and $\mathrm{PI}(3,4,5) \mathrm{P}_{3}$, while Apt $1 \Delta \mathrm{C} 82$ does not bind to any of these lipids. Both blots were imaged at the same time with identical acquisition parameters. DAG: diacylglycerol; PA: phosphatidic acid; PS: phosphatidylserine; PE: phosphatidylethanolamine; PC: phosphatidylcholine; PG: phosphatidylglycerol. (B) Live-cell imaging of the $\mathrm{Pl}(4,5) \mathrm{P}_{2}$ marker PLCठPH-GFP in control and hobbit mutant wandering L3 (wL3) salivary gland cells shows that this lipid accumulates in large intracellular compartments in hobbit mutant cells. Full genotypes- control: Sgs3>/UAS-PLC $D P H-$ GFP and hob mutant: $h o b^{2}$, Sgs3>/hob3 , UAS-PLCDPH-GFP. Scale bar $20 \mu \mathrm{m}$. 


\section{DISCUSSION}

ER-PM contact sites are critical junctures for calcium and lipid homeostasis in all eukaryotic cells. Here we have identified Hobbit as a novel protein that is enriched at ER-PM contact sites in both yeast and Drosophila. The topology of the Hobbit protein and the requirement for specific C-terminal sequences in ER-PM localization are also evolutionarily conserved. Our data demonstrates that the C-terminal Apt1 domain of Hobbit binds directly to phosphatidylinositols, and hobbit appears to play a role in regulating the subcellular distribution of these lipids. Loss of hobbit function results in lethality in Drosophila; therefore, hobbit represents a novel example of a lipid trafficking regulator that is essential for animal development.

The Pfam database (Mistry et al., 2021) annotates the Apt1 domain as a Golgi body localization domain. This annotation comes from analysis of the subcellular localization of a short Cterminal fragment of Z. mays APT1, which co-localized with a Golgi marker in vivo (Xu and Dooner, 2006). However, our data, coupled with analysis of yeast Atg2 and Vps13 and human VPS13A (Kaminska et al., 2016; Kolakowski et al., 2020; Rzepnikowska et al., 2017), suggests that the Apt1 domain represents a novel phosphatidylinositol binding domain. PI(4)P, one of the lipids that Hobbit Apt1 bound to in our study, is most highly enriched in the plasma membrane and the Golgi (Vermeer et al., 2009), suggesting that the Z. mays protein fragment may have been enriched at the Golgi due to PI(4)P binding. Interestingly, the specificity for phosphatidylinositols appears to change among divergent Apt1 domains. Fly Hobbit Apt1 bound to PI, PI(4)P, PI(4,5) $\mathrm{P}_{2}$, and $\mathrm{PI}(3,4,5) \mathrm{P}_{3}$, while yeast $\mathrm{Vps} 13$ bound to PI(3)P and human VPS13A bound to PI(3)P and PI(5)P (Kolakowski et al., 2020; Rzepnikowska et al., 2017). Thus, Apt1 domains may represent a novel family of phosphatidylinositol binding domains with varying specificity.

Given that Hobbit binds to phosphatidylinositols and that $\mathrm{PI}(4,5) \mathrm{P}_{2}$ distribution appears to be altered in hobbit mutant cells, our data suggests that hobbit may be a novel lipid transfer protein at ER-PM contact sites. Hobbit also exhibits homology to Atg2 and Vps13 in the Apt1 domain; both of these proteins mediate lipid transfer at membrane contact sites (Kumar et al., 2018; Li et al., 2020; Maeda et al., 2019; Osawa et al., 2019; Valverde et al., 2019). Several phosphatidylinositol transfer proteins (PITPs) that function at ER-PM contact sites have previously been characterized. When phospholipase C (PLC) is activated, it hydrolyzes $\mathrm{PI}(4,5) \mathrm{P}_{2}$ to generate inositol 1,4,5,-trisphosphate $\left(\mathrm{IP}_{3}\right)$ and diacylglycerol (DAG), which is subsequently converted into phosphatidic acid (PA) (Michell, 1975). PITPs are localized in the cytoplasm but 
contain domains that allow them to interact with VAPs on the ER membrane and lipids at the PM; upon hydrolysis of PI $(4,5) \mathrm{P}_{2}$, PITPs transfer PI from the ER membrane to the PM and PA from the PM to the ER membrane, thereby replenishing the PM store of PI for new synthesis of $\mathrm{PI}(4,5) \mathrm{P}_{2}$ and allowing recycling of PA in the ER (Cockcroft et al., 2016; Kim et al., 2015; Milligan et al., 1997; Saheki and De Camilli, 2017; Yadav et al., 2015). Hobbit is different from known PITPs in that it is anchored in the ER membrane and binds to both ER-enriched PI as well as to PM-enriched $\mathrm{PI}(4) \mathrm{P}, \mathrm{PI}(4,5) \mathrm{P}_{2}$, and $\mathrm{PI}(3,4,5) \mathrm{P}_{3}$. Future work will be required to directly test if Hobbit functions as a lipid transfer protein in vitro and, if so, which lipids are transferred by Hobbit. If hobbit does function as a lipid transfer protein, it would be the first such example of a lipid transfer protein that is essential for animal development.

The most conspicuous phenotype in Drosophila hobbit mutant animals is a dramatic reduction in body size caused by failure to secrete insulin from the IPCs; hobbit mutant animals also exhibit defects in regulated exocytosis of mucin-like 'glue' proteins from the larval salivary glands (Neuman and Bashirullah, 2018). Interestingly, mutation of the Z. mays and A. thaliana orthologs of hobbit causes defects in root hair tip growth and pollen tube growth, and both of these processes are highly dependent upon secretion (Guan et al., 2013; Procissi et al., 2003; Xu and Dooner, 2006). Thus, there appears to be an evolutionarily shared requirement for hobbit function in cells with high secretory loads. However, our data presented here suggests that the molecular function of hobbit lies in the regulation of phosphatidylinositol homeostasis, indicating that the effects on secretion may be indirect. Phosphatidylinositols play essential roles in regulating intracellular trafficking, both in defining membrane identity and in ensuring the recruitment of the proper subset of proteins to the appropriate organelle membrane (Balla, 2013); therefore, disruption of phosphatidylinositol subcellular distribution would be expected to interfere with membrane trafficking. We do not observe widespread membrane trafficking defects in hobbit mutant cells; instead, regulated exocytosis appears to be specifically affected. The impact of phosphatidylinositol dynamics on regulated exocytosis in hobbit mutant cells remains an important open question. 


\section{MATERIALS AND METHODS}

\section{Yeast media and genetics}

Standard recipes were used for YPD and synthetic drop out media (Sherman, 2002). Drop out media was used for selection and retention of plasmids. All imaging experiments were done using synthetic complete or drop out media. Gene deletions and GFP-fusions were made following standard genetic techniques (Longtine et al., 1998).

\section{Yeast imaging}

$1 \mathrm{~mL}$ of mid-log cultures grown in synthetic media were spun down, and all but $~ 50 \mu \mathrm{L}$ of media were aspirated. The pellet was then re-suspended in the remaining media, resulting in a concentrated suspension of cells. Cells were then imaged on a DeltaVision RT system, using a DV Elite CMOS camera and a 100x objective. Image deconvolution was performed using DeltaVision software (softWoRx 6.5.2).

\section{Yeast protease protection assay}

40 OD of cells were collected from mid-log cultures grown in YPD. Cell pellets were resuspended in pre-spheroplast media (100 mM Tris $\mathrm{pH}$ 8, $10 \mathrm{mM}$ DTT) and incubated for $10 \mathrm{~min}$ at room temperature. Cells were spun down and re-suspended in $4 \mathrm{~mL}$ spheroplast buffer $(0.1$ $\mathrm{M}$ phosphocitrate, $1.0 \mathrm{M}$ sorbitol, $0.5 \mathrm{mg} / \mathrm{mL}$ zymolyase) and incubated at $30^{\circ} \mathrm{C}$ for $30 \mathrm{~min}$. Cells were then spun down and washed with $4 \mathrm{~mL} 0.1 \mathrm{M}$ phosphocitrate, $1 \mathrm{M}$ sorbitol. To lyse cells, cells were spun down and re-suspended in $4.3 \mathrm{~mL}$ lysis buffer (50 mM Tris pH 7.5, 0.6 M sorbitol), then the suspension was dounced 15 times. The lysis product was spun at 500xg for 5 min to remove intact cells, and $200 \mathrm{uL}$ of the supernatant was taken as the input sample. The remaining supernatant was centrifuged at 40,000xg for $10 \mathrm{~min}$. The supernatant was discarded, and the pellet was resuspended in $100 \mu \mathrm{L}$ lysis buffer. The resuspended pellet was then split into 3 tubes, $33 \mu \mathrm{L}$ each. Tube one was used as a mock experiment. The second tube was the protease protection experiment, and contained $0.12 \mu \mathrm{g} / \mathrm{mL}$ proteinase $\mathrm{K}$. The third tube was the protease positive control experiment and contained $0.12 \mu \mathrm{g} / \mathrm{mL}$ proteinase $\mathrm{K}$ and $1 \%$ Triton X-100 to disrupt membranes. The tubes were incubated for $25 \mathrm{~min}$ at room temperature. To destroy proteinase K function, $3 \mu \mathrm{L} 0.2$ M PMSF was added, followed by $33 \mu \mathrm{L} 2 \mathrm{x}$ sample buffer (150 mM Tris $\mathrm{HCl}, \mathrm{pH}$ 6.8, $7 \mathrm{M}$ urea, 10\% SDS, 24\% glycerol, bromophenol blue). The input fraction was precipitated in 10\% TCA and re-suspended in $100 \mu \mathrm{L} 2 x$ sample buffer. Samples were heated at $42^{\circ} \mathrm{C}$ for $7 \mathrm{~min}$ then loaded on an $11 \%$ SDS page gel for western blotting using 
standard procedures. Mouse anti-GFP (B2) (Santa Cruz sc-9996) was diluted to 1:500 and rabbit anti-Kar2 (a gift from R. Schekman, University of California at Berkeley) was diluted to 1:20,000.

\section{Electron microscopy and analysis of ER-PM contact sites in yeast}

Yeast cells were grown overnight in YPD or YPGal and harvested during mid-log growth phase. Cell fixing and staining procedure were performed as previously described (Jorgensen et al., 2020). For quantification of ER-PM contacts, the researcher was blinded to the strain and growth conditions of cells in the EM images. ImageJ was used to measure the length of the PM from each cell by tracing the PM using the freehand line tool, then measuring the length of each ERPM contact site using the same tool. The sum of the ER-PM contact measurements was then divided by the total length of the PM of each image. These values were used to calculate the average cER/PM ratio for each strain.

\section{Sequence alignments and conservation analysis}

To identify highly conserved protein sequences in Fmp27, the S. cerevisiae Fmp27 protein sequence was aligned with the orthologous protein sequence from K. naganishii, T. blattae, $K$. capsulate, C. albicans, C. beticola, N. crassa, U. maydis, A. flavus, and S. pombe. The multiple sequence alignment was performed using MAFFT version 7 (Katoh et al., 2018; Kuraku et al., 2013). For the Drosophila protein, an alignment was performed between D. melanogaster hobbit and its orthologs in D. willistoni, D. ananassae, D. erecta, D. simulans, D. sechellia, D. grimshawi, D. virilis, D. mojavensis, and D. busckii using ClustalOmega (Sievers et al., 2011). For both yeast and Drosophila, the alignments were visualized in Jalview (Waterhouse et al., 2009) and conservation scores were extracted at each position to generate the identity plots.

\section{Drosophila stocks, husbandry, and body size/lethal phase analysis}

The following fly stocks were obtained from the Bloomington Drosophila Stock Center: UASKDEL-RFP, UAS-mTagBFP2, Sgs3-GAL4, Sgs3-GFP, act-GAL4, UAS-PLCסPH-GFP. UAS-hobbitGFP and the hobbit mutant alleles were previously described (Neuman and Bashirullah, 2018). We have used the ">" symbol in genotypes as shorthand for "GAL4." All experimental crosses were grown on standard cornmeal-molasses media in uncrowded bottles or vials kept in an incubator set to $25^{\circ} \mathrm{C}$. Body size quantification was performed as previously described (Neuman and Bashirullah, 2018). Pupa images were captured on an Olympus SXZ16 stereomicroscope coupled to an Olympus DP72 digital camera with DP2-BSW software. For lethal phase analysis, pupae were allowed to age on grape agar plates at $25^{\circ} \mathrm{C}$ for one week; then, Bainbridge and Bownes staging criteria (Bainbridge and Bownes, 1981) were used to determine lethal phase. 


\section{Drosophila transgene generation}

To generate UAS-hobbit $\triangle$ C82-GFP, the pENTR 1A-hobbit plasmid (Neuman and Bashirullah, 2018) was digested with SpeI and NotI. The following primers were annealed, phorphorylated, and ligated into $p E N T R$ 1A-hobbit: 5'-CTA GTC ATA CCT ACG CTG GAG TAT CAC AAT GTG ACG AAG C-3' and 5'-GGC CGC TTC GTC ACA TTG TGA TAC TCC AGC GTA GGT ATG A-3'. The resulting plasmid ( $p E N T R$ 1A-hobbit $\triangle C 82$ ) was sequence-verified and recombined into the Gateway cloning destination vector pBID-UASC-G-GFP (Neuman and Bashirullah, 2018; Wang et al., 2012) using LR Clonase (Invitrogen). Successful recombination was confirmed by sequencing. To generate UAS-hobbit $\triangle$ C82-mCherry, mCherry was first amplified from $p L V$ $m$ Cherry (Addgene) using the following primers: 5' - ACA GGT ACC AGT GAG CAA GGG CGA GGA GGA T-3' and 5'- ACA TCT AGA TAC TTG TAC AGC TCG TCC ATG-3'. The resulting PCR product was digested with $K p n \mathrm{I}$ and $\mathrm{Xba \textrm {I }}$ and ligated into $p B I D-U A S C-G-G F P$ (thereby replacing GFP with mCherry). The $p E N T R$ 1A-hobbit $\triangle C 82$ entry clone was recombined into pBID-UASC-G-mCherry as described above and sequence-verified. Similarly, the $p E N T R$ 1Ahobbit entry vector was recombined into $p B I D-U A S C-G-m C h e r r y$ to generate UAS-hobbit-mCherry and was sequence-verified. To generate UAS-hobbit $\triangle N 117-G F P, p E N T R$ 1A-hobbit was digested with KpnI and AgeI. The resulting $\sim 0.8 \mathrm{~kb}$ fragment was used as a template for PCR with the following primers: 5' - AAA GGT ACC CAA CAT GGC CTC GGA GGC GAA GGG TGT-3' and 5'-5' AAA ACC GGT CGA TGT CCT CCG CTT GGC CT-3'. The resulting $0.37 \mathrm{~kb}$ fragment was digested with KpnI and AgeI and ligated into pENTR 1A-hobbit; the pENTR 1A-hobbit $\triangle N 117$ entry vector was recombined into $p B I D-U A S C-G-G F P$ as described above and sequence-verified. All final plasmids were injected into VK00027 flies for phiC31-mediated site-directed integration using standard techniques (Rainbow Transgenic Flies, Inc.). To generate UAS-StimDDAA-GFP transgenic flies, plasmid LD45776 containing the cDNA sequence of Drosophila Stim Isoform A was obtained from the Drosophila Genomics Resource Center (DGRC). The Stim coding sequence was cloned by PCR using primers 5'-CAC CAT GCG AAA GAA TAC CAT TTG GAA C-3' and 5'-TTC CGT GGC AAG CAG CGA AAA GTT C-3' and ligated into $p E N T R / D-T O P O$ (Invitrogen). Site-directed mutagenesis (Stratagene QuikChange XL) was then used to convert the codons encoding D155 and D157 to codons for alanine using the primer 5'- GCT TGC ATC GTC AGC TAG CTG ATG CCG ATA ATG GAA ACA TCG-3' and its reverse complement, followed by sequence confirmation. The Stim $D D A A$ coding sequence was then recombined into the pPWG destination vector (Carnegie Drosophila Gateway Vector Collection), which introduces a UASp promter and C-terminal EGFP tag, using LR Clonase. The final plasmid was 
injected into $w^{1118}$ embryos for generation of transgenic animals by random transposable element insertion.

\section{Protein expression, purification, and lipid blots}

The Apt1 fragment of the Hobbit protein (amino acids 1750-2300) and Apt1 $\triangle \mathrm{C} 82$ (amino acids 1750-2218) were amplified from the pENTR 1A-hobbit plasmid (described above) using the following primers: Apt1 F 5'- ATC CGG TAC CCA ACA TGG TAG TCT CAG AGA CTG TTG GAG CTT TCT TGA GCG AC-3' and Apt1 R 5'- GCA TAA GCT TCT AAT GAT GAT GAT GAT GAT GGC TGC CGC CGC CGC CCA GCT CCT CCT TGC TCT CCC GG-3'; Apt1 $\triangle$ C82 F 5'ATC CGG TAC CCA ACA TGG TAG TCT CAG AGA CTG TTG GAG CTT TCT TGA GCG AC-3' and Apt1 $\triangle \mathrm{C} 82$ R 5'- GCA TAA GCT TCT AAT GAT GAT GAT GAT GAT GGC TGC CGC CGC CGC CCC ACG TCA CAT TGT GAT ACT CCA GCG-3'. The reverse primers include a Cterminal five amino acid spacer and a 6x-His tag. The resulting PCR products were digested with KpnI and HindIII, ligated into pTRC99a (Amann et al., 1988), and sequence-verified. Plasmids were transformed into E. coli EXPRESS BL21(DE3) chemically competent cells (Lucigen). A dense overnight culture was diluted 1:100 into $15 \mathrm{~mL} \mathrm{LB}$ (Miller) with $100 \mu \mathrm{g} / \mathrm{mL}$ ampicillin. Cultures were grown at $37{ }^{\circ} \mathrm{C}$ to $\mathrm{A}_{600} \sim 0.4$, then $200 \mathrm{uM}$ IPTG (final concentration) was added and cultures continued shaking for $3 \mathrm{~h}$ at $37{ }^{\circ} \mathrm{C}$. Cultures were then centrifuged for $5 \mathrm{~min}$ at $5000 \mathrm{xg}$, and pellets were frozen at $-80^{\circ} \mathrm{C}$. For protein purification, pellets were thawed on ice for $15 \mathrm{~min}$, resuspended in $3 \mathrm{~mL}$ lysis buffer $\left(50 \mathrm{mM} \mathrm{NaH} \mathrm{PO}_{4}, 300 \mathrm{mM} \mathrm{NaCl}, 10 \mathrm{mM}\right.$ imidazole, $\mathrm{pH} 8$ ) with $1 \mathrm{mg} / \mathrm{mL}$ lysozyme (final concentration), $1.5 \mu \mathrm{L}$ Benozoase nuclease (Sigma), and $1 \mu \mathrm{L}$ protease inhibitor cocktail (Sigma P8849), incubated on ice for $30 \mathrm{~min}$, and centrifuged for $30 \mathrm{~min}$ at $10,000 \mathrm{xg}$ at $4^{\circ} \mathrm{C} .1 .5 \mathrm{~mL}$ of Ni-NTA agarose (Qiagen) was washed three times with lysis buffer. Cleared lysate and washed Ni-NTA agarose were combined and incubated for $1 \mathrm{~h}$ at $4^{\circ} \mathrm{C}$ while rotating on a nutator. The slurry was loaded onto a gravity column, washed two times with $1 \mathrm{~mL}$ wash buffer $\left(50 \mathrm{mM} \mathrm{NaH} \mathrm{PO}_{4}, 300 \mathrm{mM} \mathrm{NaCl}, 20 \mathrm{mM}\right.$ imidazole, $\mathrm{pH}$ 8), and eluted four times with $0.5 \mathrm{~mL}$ elution buffer $\left(50 \mathrm{mM} \mathrm{NaH}{ }_{2} \mathrm{PO}_{4}, 300 \mathrm{mM}\right.$ $\mathrm{NaCl}, 250 \mathrm{mM}$ imidazole, $\mathrm{pH}$ 8). Proteins were visualized on 4-20\% Mini-PROTEAN TGX precast gels (BioRad) and concentration was determined using the Bradford Protein Assay (BioRad). For lipid blotting experiments, Membrane Lipid Strips (Echelon Biosciences) were blocked in PBS with 0.1\% Tween-20 (PBST) /3\% BSA overnight while rotating at $4^{\circ} \mathrm{C}$. The strips were then incubated for $1 \mathrm{~h}$ at room temperature with $1.5 \mathrm{mg}$ of purified protein diluted in PBST/3\% BSA to a $15 \mathrm{~mL}$ final volume. A 1:10,000 dilution of mouse $\alpha$-(6X)His (Invitrogen) primary antibody in PBST/3\% BSA was applied for $1 \mathrm{~h}$ at room temperature, followed by a 1:20,000 dilution of anti-mouse IgG HRP conjugated secondary antibody (Promega) for $1 \mathrm{~h}$ at 
room temperature. Washes with PBST were performed between each step. Lipid strips were then incubated for $5 \mathrm{~min}$ with SuperSignal West Pico PLUS Chemiluminescent Reagent (Thermo) and visualized using a UVP ChemiDoc-It ${ }^{2}$. Image brightness and contrast were optimized post-acquisition using Adobe Photoshop CS6.

\section{Confocal microscopy in Drosophila salivary glands}

All images were obtained from live, unfixed tissues. Salivary glands were dissected from animals of the appropriate developmental stage and genotype in PBS and mounted in 1\% lowmelt agarose (Apex Chemicals) made in PBS. Tissues were imaged for no more than 15 min after mounting, and at least 10 salivary glands were imaged per experiment. Imaging was carried out at room temperature. Images were acquired using an Olympus FV3000 laser scanning confocal microscope (20x objective, NA 0.75 or 100x oil immersion objective, NA 1.49) with FV31S-SW software. The pinhole was closed down to 0.8 Airy disc for images acquired at high resolution (Fig. 4A, B, Fig. S3B). Images obtained as z-stacks, as indicated in the figure legends, were deconvolved using three iterations of the Olympus CellSens Deconvolution for Laser Scanning Confocal Advanced Maximum Likelihood algorithm. Brightness and contrast were optimized post-acquisition using Olympus FV31S-SW software. For imaging-based protease protection assays, salivary glands were adhered to a plastic coverslip in a minimal quantity of PBS; after at least $30 \mathrm{~s}$ of time-lapse image acquisition using the Olympus FV3000 resonant scan head, $50 \mu \mathrm{L}$ of $0.05 \%$ digitonin (Invitrogen) was added, followed by an additional at least 1 min of imaging. Then we added $75 \mu \mathrm{L}$ of $50 \mu \mathrm{g} / \mathrm{mL}$ proteinase K (Fisher Scientific), followed by at least 2 min of imaging. 


\section{ACKNOWLEDGEMENTS}

Reagents obtained from the Bloomington Drosophila Stock Center (NIH P40OD018537) and Drosophila Genomics Resource Center (NIH 2P40OD010949) were used in this study.

\section{COMPETING INTERESTS}

The authors declare no competing interests.

\section{FUNDING}

This work was supported in part by the National Institutes of Health (GM123204 to A.B.) and by a Cornell University Research Grant to S.D.E.

\section{AUTHOR CONTRIBUTIONS}

Conceptualization: S.D.N., J.R.J., S.D.E., A.B; Methodology: S.D.N., J.R.J., S.D.E., A.B.; Validation: S.D.N., J.R.J., S.D.E., A.B.; Investigation: S.D.N., J.R.J., A.T.C., J.T.S., J.E.S.; Data curation: S.D.N., J.R.J.; Writing- original draft: S.D.N.; Writing- review and editing: S.D.N., J.R.J., J.T.S., S.D.E., A.B.; Visualization: S.D.N., J.R.J., S.D.E., A.B.; Supervision: S.D.E., A.B.; Project administration: S.D.E., A.B.; Funding acquisition: J.T.S., S.D.E., A.B. 


\section{REFERENCES}

Aeschbacher, R.A., Hauser, M.T., Feldmann, K.A., Benfey, P.N., 1995. The SABRE gene is required for normal cell expansion in Arabidopsis. Genes Dev. 9, 330-340. https: / doi.org/ 10.1101/gad.9.3.330

Amann, E., Ochs, B., Abel, K.J., 1988. Tightly regulated tac promoter vectors useful for the expression of unfused and fused proteins in Escherichia coli. Gene 69, 301-315. https:/ / doi.org/10.1016/0378-1119(88)90440-4

Baba, Y., Nishida, K., Fujii, Y., Hirano, T., Hikida, M., Kurosaki, T., 2008. Essential function for the calcium sensor STIM1 in mast cell activation and anaphylactic responses. Nat. Immunol. 9, 81-88. https:/ / doi.org/10.1038/ni1546

Bainbridge, B.S.P., Bownes, M., 1981. Staging the metamorphosis of Drosophila melanogaster. Development 66, 57-80.

Balla, T., 2013. Phosphoinositides: Tiny Lipids With Giant Impact on Cell Regulation. Physiol. Rev. 93, 1019-1137. https: / / doi.org/10.1152/ physrev.00028.2012

Benfey, P.N., Linstead, P.J., Roberts, K., Schiefelbein, J.W., Hauser, M.T., Aeschbacher, R.A., 1993. Root development in Arabidopsis: Four mutants with dramatically altered root morphogenesis. Development 119, 57-70.

Cheng, X., Bezanilla, M., 2020. SABRE populates ER domains essential for cell plate maturation and cell expansion influencing cell and tissue patterning. bioRxiv. https: / / doi.org/ $10.1101 / 2020.11 .24 .396788$

Cockcroft, S., Garner, K., Yadav, S., Gomez-Espinoza, E., Raghu, P., 2016. RdgB $\alpha$ reciprocally transfers PA and PI at ER-PM contact sites to maintain PI(4,5)P2 homoeostasis during phospholipase C signalling in Drosophila photoreceptors. Biochem. Soc. Trans. 44, 286-292. https: / / doi.org/10.1042/BST20150228

Cuttell, L., Vaughan, A., Silva, E., Escaron, C.J., Lavine, M., Van Goethem, E., Eid, J.P., Quirin, M., Franc, N.C., 2008. Undertaker, a Drosophila Junctophilin, Links Draper-Mediated Phagocytosis and Calcium Homeostasis. Cell 135, 524-534. https: / doi.org/10.1016/ j.cell.2008.08.033

Eisenberg-Bord, M., Shai, N., Schuldiner, M., Bohnert, M., 2016. A Tether Is a Tether Is a Tether: Tethering at Membrane Contact Sites. Dev. Cell. https: / / doi.org/10.1016/ j.devcel.2016.10.022 
Feske, S., Gwack, Y., Prakriya, M., Srikanth, S., Puppel, S.H., Tanasa, B., Hogan, P.G., Lewis, R.S., Daly, M., Rao, A., 2006. A mutation in Orai1 causes immune deficiency by abrogating CRAC channel function. Nature 441, 179-185. https: / / doi.org/10.1038/ nature04702

Giordano, F., Saheki, Y., Idevall-Hagren, O., Colombo, S.F., Pirruccello, M., Milosevic, I., Gracheva, E.O., Bagriantsev, S.N., Borgese, N., De Camilli, P., 2013. PI(4,5)P2-Dependent and Ca2+-Regulated ER-PM interactions mediated by the extended synaptotagmins. Cell 153, 1494-1509. https: / / doi.org/10.1016/j.cell.2013.05.026

Guan, Y., Guo, J., Li, H., Yang, Z., 2013. Signaling in pollen tube growth: Crosstalk, feedback, and missing links. Mol. Plant. https: / / doi.org/10.1093/mp/sst070

Gwack, Y., Srikanth, S., Oh-hora, M., Hogan, P.G., Lamperti, E.D., Yamashita, M., Gelinas, C., Neems, D.S., Sasaki, Y., Feske, S., Prakriya, M., Rajewsky, K., Rao, A., 2008. Hair Loss and Defective T- and B-Cell Function in Mice Lacking ORAI1. Mol. Cell. Biol. 28, 5209-5222. https: / / doi.org/10.1128/mcb.00360-08

Henne, W.M., Liou, J., Emr, S.D., 2015. Molecular mechanisms of inter-organelle ER-PM contact sites. Curr. Opin. Cell Biol. https: / / doi.org/10.1016/j.ceb.2015.05.001

Hogan, P.G., Rao, A., 2015. Store-operated calcium entry: Mechanisms and modulation. Biochem. Biophys. Res. Commun. https:/ / doi.org/10.1016/j.bbrc.2015.02.110

Jorgensen, J.R., Tei, R., Baskin, J.M., Michel, A.H., Kornmann, B., Emr, S.D., 2020. ESCRT-III and ER-PM contacts maintain lipid homeostasis. Mol. Biol. Cell 31, 1302-1313. https:/ / doi.org/10.1091/mbc.E20-01-0061

Kaminska, J., Rzepnikowska, W., Polak, A., Flis, K., Soczewka, P., Bala, K., Sienko, M., Grynberg, M., Kaliszewski, P., Urbanek, A., Ayscough, K., Zoladek, T., 2016. Phosphatidylinositol-3phosphate regulates response of cells to proteotoxic stress. Int. J. Biochem. Cell Biol. 79, 494-504. https:/ / doi.org/10.1016/j.biocel.2016.08.007

Katoh, K., Rozewicki, J., Yamada, K.D., 2018. MAFFT online service: Multiple sequence alignment, interactive sequence choice and visualization. Brief. Bioinform. 20, 1160-1166. https: / / doi.org/10.1093/bib/bbx108

Kim, Y.J., Guzman-Hernandez, M.L., Wisniewski, E., Balla, T., 2015. PhosphatidylinositolPhosphatidic Acid Exchange by Nir2 at ER-PM Contact Sites Maintains Phosphoinositide Signaling Competence. Dev. Cell 33, 549-561. https:/ / doi.org/10.1016/j.devcel.2015.04.028

Kolakowski, D., Kaminska, J., Zoladek, T., 2020. The binding of the APT1 domains to 
phosphoinositides is regulated by metal ions in vitro. Biochim. Biophys. Acta - Biomembr. 1862, 183349. https: / / doi.org/10.1016/j.bbamem.2020.183349

Kumar, N., Leonzino, M., Hancock-Cerutti, W., Horenkamp, F.A., Li, P.Q., Lees, J.A., Wheeler, H., Reinisch, K.M., De Camilli, P., 2018. VPS13A and VPS13C are lipid transport proteins differentially localized at ER contact sites. J. Cell Biol. 217, 3625-3639. https: / / doi.org/ 10.1083/JCB.201807019

Kuraku, S., Zmasek, C.M., Nishimura, O., Katoh, K., 2013. aLeaves facilitates on-demand exploration of metazoan gene family trees on MAFFT sequence alignment server with enhanced interactivity. Nucleic Acids Res. 41, W22-W28. https: / / doi.org/10.1093/nar/ gkt389

Kyte, J., Doolittle, R.F., 1982. A simple method for displaying the hydropathic character of a protein. J. Mol. Biol. 157, 105-132. https: / / doi.org/10.1016/0022-2836(82)90515-0

Li, P.Q., Lees, J.A., Patrick Lusk, C., Reinisch, K.M., 2020. Cryo-EM reconstruction of a VPS13 fragment reveals a long groove to channel lipids between membranes. J. Cell Biol. 219. https: / / doi.org/10.1083/jcb.202001161

Liou, J., Kim, M.L., Won, D.H., Jones, J.T., Myers, J.W., Ferrell, J.E., Meyer, T., 2005. STIM is a $\mathrm{Ca} 2+$ sensor essential for Ca2+-store- depletion-triggered Ca2+ influx. Curr. Biol. 15, 12351241. https: / / doi.org/10.1016/j.cub.2005.05.055

Longtine, M.S., McKenzie, A., Demarini, D.J., Shah, N.G., Wach, A., Brachat, A., Philippsen, P., Pringle, J.R., 1998. Additional modules for versatile and economical PCR-based gene deletion and modification in Saccharomyces cerevisiae. Yeast 14, 953-961. https:/ / doi.org/ 10.1002 / (SICI)1097-0061(199807)14:10<953::AID-YEA293>3.0.CO;2-U

Lorenz, H., Hailey, D.W., Lippincott-Schwartz, J., 2006. Fluorescence protease protection of GFP chimeras to reveal protein topology and subcellular localization. Nat. Methods 3, 205-210. https: / / doi.org/10.1038/nmeth857

Lunz, V., Romanin, C., Frischauf, I., 2019. STIM1 activation of Orai1. Cell Calcium. https:/ / doi.org/10.1016/j.ceca.2018.11.009

Maeda, S., Otomo, C., Otomo, T., 2019. The autophagic membrane tether ATG2A transfers lipids between membranes. Elife 8. https: / / doi.org/10.7554/eLife.45777

Manford, A.G., Stefan, C.J., Yuan, H.L., MacGurn, J.A., Emr, S.D., 2012. ER-to-Plasma Membrane Tethering Proteins Regulate Cell Signaling and ER Morphology. Dev. Cell 23, 1129-1140. 
https: / / doi.org/10.1016/j.devcel.2012.11.004

Michell, R.H., 1975. Inositol phospholipids and cell surface receptor function. BBA - Rev.

Biomembr. https: / / doi.org/10.1016/0304-4157(75)90017-9

Milligan, S.C., Alb, J.G., Elagina, R.B., Bankaitis, V.A., Hyde, D.R., 1997. The

phosphatidylinositol transfer protein domain of Drosophila retinal degeneration B protein is essential for photoreceptor cell survival and recovery from light stimulation. J. Cell Biol. 139, 351-363. https: / / doi.org/10.1083/jcb.139.2.351

Mistry, J., Chuguransky, S., Williams, L., Qureshi, M., Salazar, G.A., Sonnhammer, E.L.L., Tosatto, S.C.E., Paladin, L., Raj, S., Richardson, L.J., Finn, R.D., Bateman, A., 2021. Pfam: The protein families database in 2021. Nucleic Acids Res. 49, D412-D419. https:/ / doi.org/ 10.1093 / nar / gkaa913

Murphy, S.E., Levine, T.P., 2016. VAP, a Versatile Access Point for the Endoplasmic Reticulum: Review and analysis of FFAT-like motifs in the VAPome. Biochim. Biophys. Acta - Mol. Cell Biol. Lipids 1861, 952-961. https: / / doi.org/10.1016/j.bbalip.2016.02.009

Neuman, S.D., Bashirullah, A., 2018. Hobbit regulates intracellular trafficking to drive insulindependent growth during Drosophila development. Development 145, dev161356. https: / / doi.org/10.1242/ dev.161356

Oh-hora, M., Yamashita, M., Hogan, P.G., Sharma, S., Lamperti, E., Chung, W., Prakriya, M., Feske, S., Rao, A., 2008. Dual functions for the endoplasmic reticulum calcium sensors STIM1 and STIM2 in T cell activation and tolerance. Nat. Immunol. 9, 432-443. https:/ / doi.org/10.1038/ni1574

Omnus, D.J., Manford, A.G., Bader, J.M., Emr, S.D., Stefan, C.J., 2016. Phosphoinositide kinase signaling controls ER-PM cross-talk. Mol. Biol. Cell 27, 1170-1180. https: / / doi.org/ 10.1091/mbc.E16-01-0002

Osawa, T., Kotani, T., Kawaoka, T., Hirata, E., Suzuki, K., Nakatogawa, H., Ohsumi, Y., Noda, N.N., 2019. Atg2 mediates direct lipid transfer between membranes for autophagosome formation. Nat. Struct. Mol. Biol. 26, 281-288. https: / / doi.org/10.1038/ s41594-019-0203-4

Pathak, T., Trivedi, D., Hasan, G., 2017. CRISPR-Cas-induced mutants identify a requirement for dSTIM in larval dopaminergic cells of Drosophila melanogaster. G3 Genes, Genomes, Genet. 7, 923-933. https: / / doi.org/10.1534/g3.116.038539

Pichler, H., Gaigg, B., Hrastnik, C., Achleitner, G., Kohlwein, S.D., Zellnig, G., Perktold, A., 
Daum, G., 2001. A subfraction of the yeast endoplasmic reticulum associates with the plasma membrane and has a high capacity to synthesize lipids. Eur. J. Biochem. 268, 23512361. https: / / doi.org/10.1046/j.1432-1327.2001.02116.x

Pietra, S., Gustavsson, A., Kiefer, C., Kalmbach, L., Hörstedt, P., Ikeda, Y., Stepanova, A.N., Alonso, J.M., Grebe, M., 2013. Arabidopsis SABRE and CLASP interact to stabilize cell division plane orientation and planar polarity. Nat. Commun. 4, 1-15. https: / doi.org/ $10.1038 /$ ncomms3779

Pietra, S., Lang, P., Grebe, M., 2015. SABRE is required for stabilization of root hair patterning in Arabidopsis thaliana. Physiol. Plant. 153, 440-453. https: / / doi.org/10.1111/ppl.12257

Porter, K.R., Palade, G.E., 1957. Studies on the endoplasmic reticulum. III. Its form and distribution in striated muscle cells. J. Biophys. Biochem. Cytol. 3, 269-300. https: / / doi.org/10.1083/jcb.3.2.269

Prinz, W.A., Toulmay, A., Balla, T., 2020. The functional universe of membrane contact sites. Nat. Rev. Mol. Cell Biol. 21, 7-24. https: / / doi.org/10.1038/ s41580-019-0180-9

Procissi, A., Guyon, A., Pierson, E.S., Giritch, A., Knuiman, B., Grandjean, O., Tonelli, C., Derksen, J., Pelletier, G., Bonhomme, S., 2003. Kinky Pollen encodes a Sabre-like protein required for tip growth in Arabidopsis and conserved among eukaryotes. Plant J. 36, 894904. https: / / doi.org/10.1046/j.1365-313X.2003.01933.x

Quon, E., Sere, Y.Y., Chauhan, N., Johansen, J., Sullivan, D.P., Dittman, J.S., Rice, W.J., Chan, R.B., Di Paolo, G., Beh, C.T., Menon, A.K., 2018. Endoplasmic reticulum-plasma membrane contact sites integrate sterol and phospholipid regulation. PLoS Biol. 16, e2003864. https: / / doi.org/10.1371/ journal.pbio.2003864

Reinders, J., Zahedi, R.P., Pfanner, N., Meisinger, C., Sickmann, A., 2006. Toward the complete yeast mitochondrial proteome: Multidimensional separation techniques for mitochondrial proteomics. J. Proteome Res. 5, 1543-1554. https:/ / doi.org/10.1021/pr050477f

Roos, J., DiGregorio, P.J., Yeromin, A. V., Ohlsen, K., Lioudyno, M., Zhang, S., Safrina, O., Kozak, J.A., Wagner, S.L., Cahalan, M.D., Veliçelebi, G., Stauderman, K.A., 2005. STIM1, an essential and conserved component of store-operated Ca $2+$ channel function. J. Cell Biol. 169, 435-445. https: / / doi.org/10.1083/jcb.200502019

Rose, M.D., Misra, L.M., Vogel, J.P., 1989. KAR2, a karyogamy gene, is the yeast homolog of the mammalian BiP/GRP78 gene. Cell 57, 1211-1221. https: / / doi.org/ 


\section{$10.1016 / 0092-8674(89) 90058-5$}

Rzepnikowska, W., Flis, K., Kaminska, J., Grynberg, M., Urbanek, A., Ayscough, K.R., Zoladek, T., 2017. Amino acid substitution equivalent to human choreaacanthocytosis I2771R in yeast Vps13 protein affects its binding to phosphatidylinositol 3-phosphate. Hum. Mol. Genet. 26, 1497-1510. https: / / doi.org/10.1093/hmg/ddx054

Saheki, Y., De Camilli, P., 2017. Endoplasmic reticulum-plasma membrane contact sites. Annu. Rev. Biochem. https: / / doi.org/10.1146/ annurev-biochem-061516-044932

Schulz, T.A., Choi, M.G., Raychaudhuri, S., Mears, J.A., Ghirlando, R., Hinshaw, J.E., Prinz, W.A., 2009. Lipid-regulated sterol transfer between closely apposed membranes by oxysterol-binding protein homologues. J. Cell Biol. 187, 889-903. https: / / doi.org/10.1083/ jcb.200905007

Shai, N., Yifrach, E., Van Roermund, C.W.T., Cohen, N., Bibi, C., Ijlst, L., Cavellini, L., Meurisse, J., Schuster, R., Zada, L., Mari, M.C., Reggiori, F.M., Hughes, A.L., Escobar-Henriques, M., Cohen, M.M., Waterham, H.R., Wanders, R.J.A., Schuldiner, M., Zalckvar, E., 2018. Systematic mapping of contact sites reveals tethers and a function for the peroxisomemitochondria contact. Nat. Commun. 9. https: / / doi.org/10.1038/s41467-018-03957-8

Sherman, F., 2002. Getting started with yeast. Methods Enzymol. 350, 3-41. https:/ / doi.org/ 10.1016/S0076-6879(02)50954-X

Sievers, F., Wilm, A., Dineen, D., Gibson, T.J., Karplus, K., Li, W., Lopez, R., McWilliam, H., Remmert, M., Söding, J., Thompson, J.D., Higgins, D.G., 2011. Fast, scalable generation of high-quality protein multiple sequence alignments using Clustal Omega. Mol. Syst. Biol. 7, 539. https: / / doi.org/10.1038/ msb.2011.75

Stefan, C.J., Manford, A.G., Baird, D., Yamada-Hanff, J., Mao, Y., Emr, S.D., 2011. Osh proteins regulate phosphoinositide metabolism at ER-plasma membrane contact sites. Cell 144, 389401. https: / / doi.org/10.1016/j.cell.2010.12.034

Stiber, J., Hawkins, A., Zhang, Z.S., Wang, S., Burch, J., Graham, V., Ward, C.C., Seth, M., Finch, E., Malouf, N., Williams, R.S., Eu, J.P., Rosenberg, P., 2008. STIM1 signalling controls storeoperated calcium entry required for development and contractile function in skeletal muscle. Nat. Cell Biol. 10, 688-697. https:/ / doi.org/10.1038/ncb1731

Valm, A.M., Cohen, S., Legant, W.R., Melunis, J., Hershberg, U., Wait, E., Cohen, A.R., Davidson, M.W., Betzig, E., Lippincott-Schwartz, J., 2017. Applying systems-level spectral imaging 
and analysis to reveal the organelle interactome. Nature. https:/ / doi.org/10.1038/ nature22369

Valverde, D.P., Yu, S., Boggavarapu, V., Kumar, N., Lees, J.A., Walz, T., Reinisch, K.M., Melia, T.J., 2019. ATG2 transports lipids to promote autophagosome biogenesis. J. Cell Biol. 218, 1787-1798. https: / / doi.org/10.1083 / JCB.201811139

Vermeer, J.E.M., Thole, J.M., Goedhart, J., Nielsen, E., Munnik, T., Gadella, T.W.J., 2009. Imaging phosphatidylinositol 4-phosphate dynamics in living plant cells. Plant J. 57, 356-372. https: / / doi.org/10.1111/j.1365-313X.2008.03679.x

Verstreken, P., Ohyama, T., Haueter, C., Habets, R.L.P., Lin, Y.Q., Swan, L.E., Ly, C. V., Venken, K.J.T., De Camilli, P., Bellen, H.J., 2009. Tweek, an Evolutionarily Conserved Protein, Is Required for Synaptic Vesicle Recycling. Neuron 63, 203-215. https: / doi.org/10.1016/ j.neuron.2009.06.017

Vig, M., Peinelt, C., Beck, A., Koomoa, D.L., Rabah, D., Koblan-Huberson, M., Kraft, S., Turner, H., Fleig, A., Penner, R., Kinet, J.P., 2006. CRACM1 is a plasma membrane protein essential for store-operated Ca 2+ entry. Science (80-. ). 312, 1220-1223. https: / / doi.org/10.1126/ science. 1127883

Wang, J.-W., Beck, E.S., McCabe, B.D., 2012. A Modular Toolset for Recombination Transgenesis and Neurogenetic Analysis of Drosophila. PLoS One 7, e42102. https: / doi.org/10.1371/ journal.pone.0042102

Waterhouse, A.M., Procter, J.B., Martin, D.M.A., Clamp, M., Barton, G.J., 2009. Jalview Version 2A multiple sequence alignment editor and analysis workbench. Bioinformatics 25, 11891191. https: / / doi.org/10.1093/ bioinformatics / btp033

West, M., Zurek, N., Hoenger, A., Voeltz, G.K., 2011. A 3D analysis of yeast ER structure reveals how ER domains are organized by membrane curvature. J. Cell Biol. 193, 333-346. https: / / doi.org/10.1083/jcb.201011039

Wu, H., Carvalho, P., Voeltz, G.K., 2018. Here, there, and everywhere: The importance of ER membrane contact sites. Science (80-. ). 361. https:/ / doi.org/10.1126/ science.aan5835

Xu, Z., Dooner, H.K., 2006. The Maize aberrant pollen transmission 1 Gene Is a SABRE/KIP Homolog Required for Pollen Tube Growth. Genetics 172, 1251-1261. https: / doi.org/ 10.1534 / genetics.105.050237

Yadav, S., Garner, K., Georgiev, P., Li, M., Gomez-Espinosa, E., Panda, A., Mathre, S., 
Okkenhaug, H., Cockcroft, S., Raghu, P., 2015. RDGB $\alpha$, a PtdIns-PtdOH transfer protein, regulates G-proteincoupled PtdIns(4,5)P2 signalling during Drosophila phototransduction. J. Cell Sci. 128, 3330-3344. https: / / doi.org/10.1242/jcs.173476

Yu, H., Luo, N., Sun, L., Liu, D., 2012. HPS4/SABRE regulates plant responses to phosphate starvation through antagonistic interaction with ethylene signalling. J. Exp. Bot. 63, 45274538. https: / / doi.org/10.1093/jxb/ers131

Zhang, S.L., Yeromin, A. V., Zhang, X.H.F., Yu, Y., Safrina, O., Penna, A., Roos, J., Stauderman, K.A., Cahalan, M.D., 2006. Genome-wide RNAi screen of Ca2+ influx identifies genes that regulate $\mathrm{Ca} 2+$ release-activated Ca2+ channel activity. Proc. Natl. Acad. Sci. U. S. A. 103, 9357-9362. https: / / doi.org/10.1073 / pnas.0603161103

Zhang, S.L., Yu, Y., Roos, J., Kozak, J.A., Deerinck, T.J., Ellisman, M.H., Stauderman, K.A., Cahalan, M.D., 2005. STIM1 is a Ca2+ sensor that activates CRAC channels and migrates from the Ca2+ store to the plasma membrane. Nature 437, 902-905. https: / / doi.org/ 10.1038 / nature04147 
bioRxiv preprint doi: https://doi.org/10.1101/2021.03.02.433623; this version posted March 2, 2021. The copyright holder for this preprint (which was not certified by peer review) is the author/funder, who has granted bioRxiv a license to display the preprint in perpetuity. It is made available under aCC-BY 4.0 International license.

Figure S1. Analysis of Ypr117w and Fmp27 localization and conservation. (A) Live-cell imaging of endogenously tagged Ypr117w-GFP (green) shows that Ypr117w is enriched in puncta at the cell cortex; however, this protein was expressed at very low levels. (B) Live-cell imaging of endogenously tagged Fmp27GFP (green) with the mitochondrial marker Su9-DsRED (magenta) shows that Fmp27 does not localize to mitochondria. Su9-DsRED was expressed from a plasmid. (C) Schematic depicting the conservation of $S$. cerevisiae Fmp27 and its orthologs in nine other fungal species (see methods section for list). GFPFmp27 $\Delta$ N192 removes the first region of highly conserved sequence (192 amino acids) at the N-terminus.

A
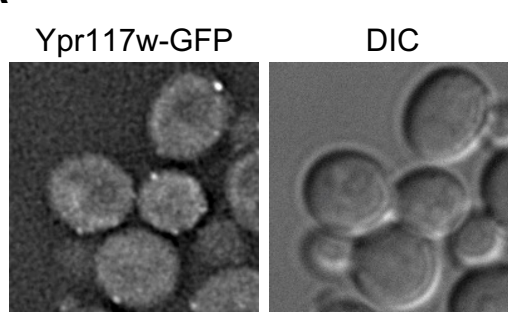

Ypr117w-GFP

B
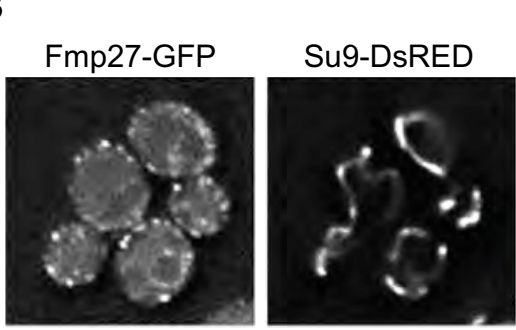

Fmp27-GFP

Su9-DsRED

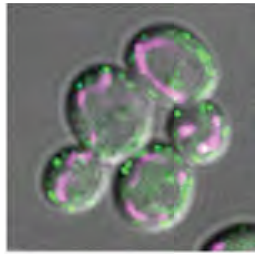

C

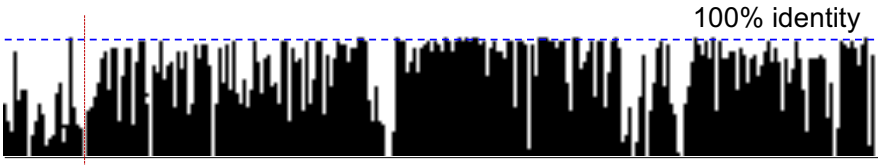

GFP-Fmp27 $\triangle \mathrm{N} 192$ 
bioRxiv preprint doi: https://doi.org/10.1101/2021.03.02.433623; this version posted March 2, 2021. The copyright holder for this preprint (which was not certified by peer review) is the author/funder, who has granted bioRxiv a license to display the preprint in perpetuity. It is made available under aCC-BY 4.0 International license.

Figure S2. Design of $\boldsymbol{D}$. melanogaster N-terminal Hobbit truncation. (A) Kyte-Doolittle hydrophobicity plot of $D$. melanogaster Hobbit shows a short, highly hydrophobic region at the $\mathrm{N}$-terminus of the protein (marked by red arrow), consistent with a possible transmembrane domain. Plot generated using Expasy ProtScale. (B) Schematic depicting the conservation of D. melanogaster Hobbit and its orthologs in nine other Drosophilid species (see methods section for list). The Hobbit $\Delta$ N117-GFP transgene removes the first region of highly conserved sequence (117 amino acids) at the $\mathrm{N}$-terminus.

A

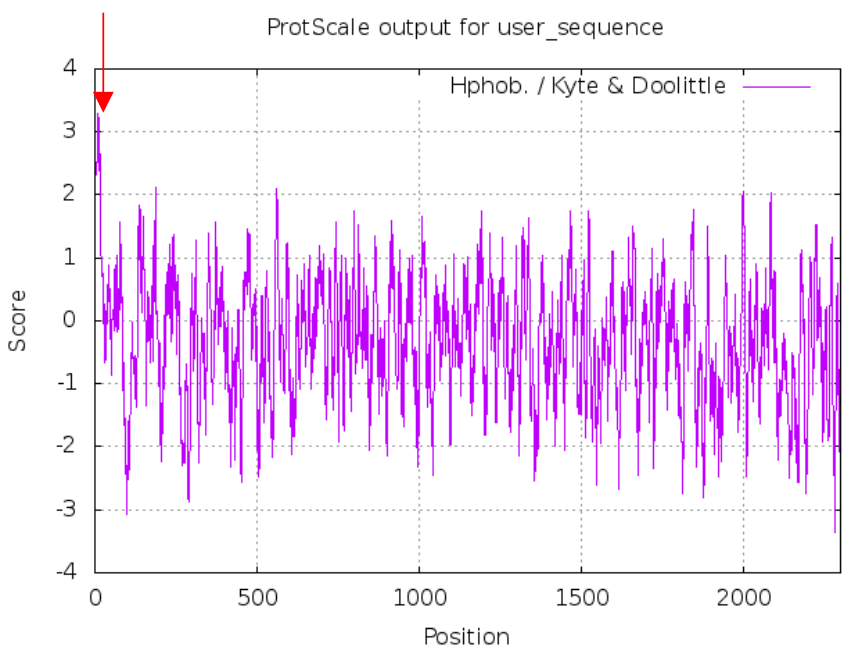

B

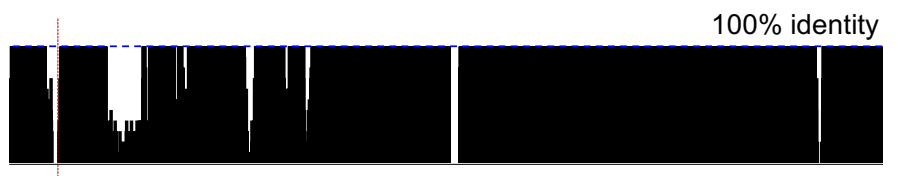

Hobbit $\triangle$ N117-GFP 
bioRxiv preprint doi: https://doi.org/10.1101/2021.03.02.433623; this version posted March 2, 2021. The copyright holder for this preprint (which was not certified by peer review) is the author/funder, who has granted bioRxiv a license to display the preprint in perpetuity. It is made available under aCC-BY 4.0 International license.

Figure S3. C-terminal truncation of Hobbit does not affect ER membrane localization or topology.

(A) Schematic depicting the conservation of D. melanogaster Hobbit and its orthologs in nine other Drosophilid species (see methods section for list) and the position of each of the identified hobbit mutant nonsense mutations. The Hobbit $\triangle$ C82-GFP transgene enables overexpression of a protein comparable to that in $h b^{5}$. (B) Live-cell imaging of Hobbit $\triangle$ C82-GFP (green), the ER lumen marker KDEL-RFP (red), and cytosolic mTagBFP2 (magenta) in salivary glands at the onset of metamorphosis $(0 \mathrm{~h}$ after puparium formation) shows that C-terminally truncated Hobbit still localizes to the ER membrane. Full genotype: UASKDEL-RFP/+; Sgs3>hobDC82-GFP/UAS-mTagBFP2. Images show a single slice from a z-stack comprising three optical sections at a $0.28 \mu \mathrm{m}$ step size. (C) Imaging-based protease protection assay shows that the Cterminal truncation of Hobbit does not affect topology. Cytosolic mTagBFP2 (top) rapidly diffuses out of the cells after permeabilization with digitonin, while Hobbit $\triangle$ C82-GFP (middle) and KDEL-RFP (bottom) are unaffected. Like the full-length protein, Hobbit $\triangle$ C82-GFP (tagged at the C-terminus) is degraded after subsequent addition of proteinase K, while KDEL-RFP is unaffected. Note that the cells flatten after addition of proteinase K. Experiment was conducted using $0 \mathrm{~h}$ PF glands. Full genotype: UAS-KDEL-RFP/+; Sgs3>hobDC82-GFP/UAS-mTagBFP2. Scale bar in (B): $1 \mu \mathrm{m}$; (C): $10 \mu \mathrm{m}$.

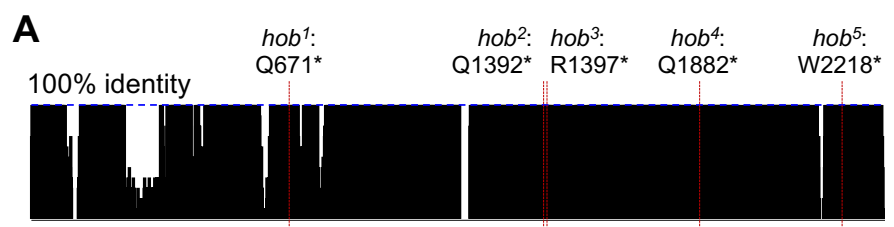

Hobbit $\triangle$ C82-GFP

B

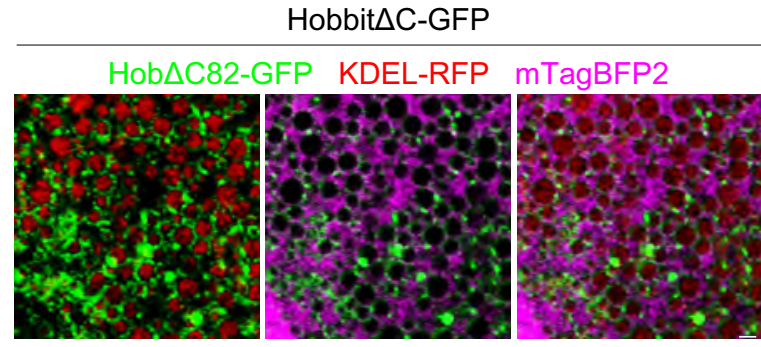

C

Hobbit $\triangle$ C-GFP

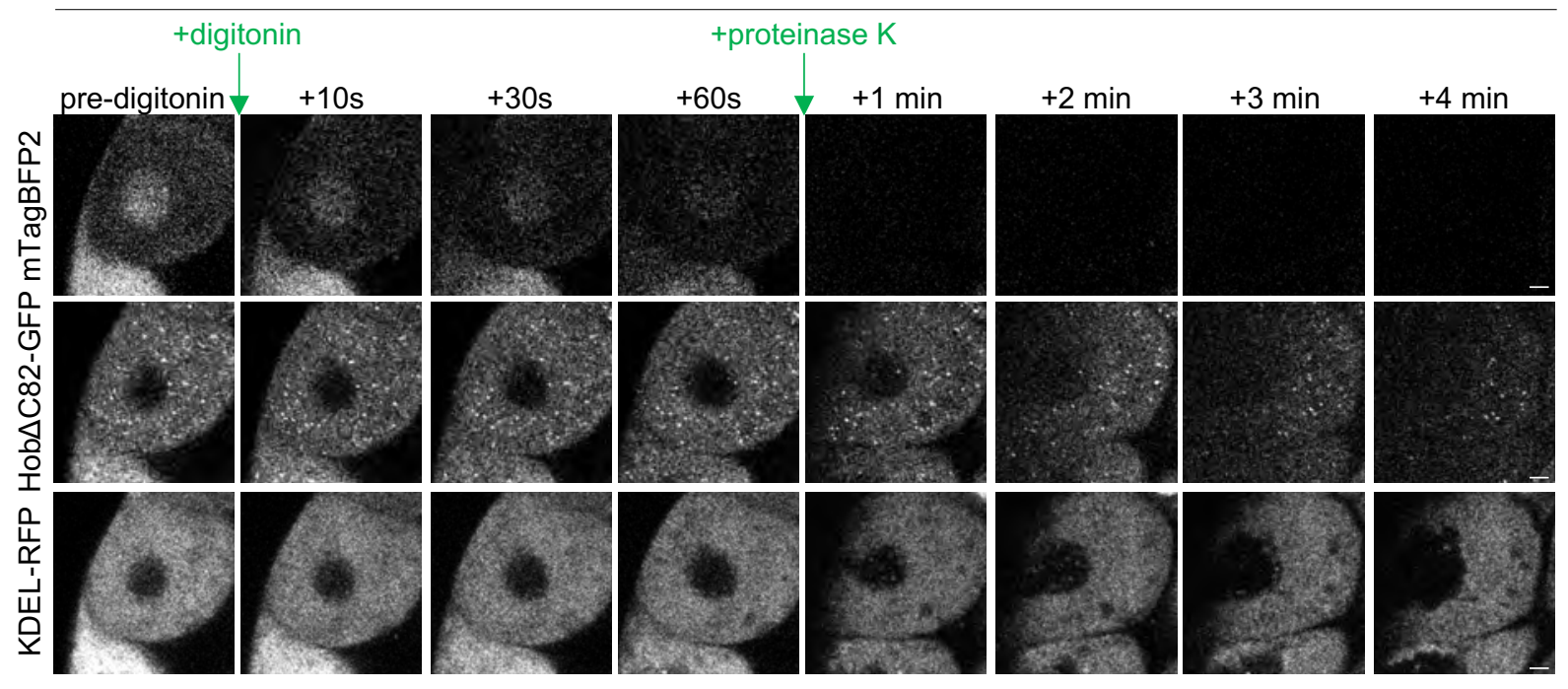

Neuman et al. 
bioRxiv preprint doi: https://doi.org/10.1101/2021.03.02.433623; this version posted March 2, 2021. The copyright holder for this preprint (which was not certified by peer review) is the author/funder, who has granted bioRxiv a license to display the preprint in perpetuity. It is made available under aCC-BY 4.0 International license.

Figure S4. C-terminal truncation of Fmp27 reduces cortical ER localization. (A) Schematic depicting the conservation of $S$. cerevisiae Fmp27 and its orthologs in nine other fungal species (see methods section for list; also displayed in Fig. S1C). Fmp27 $\Delta$ C595-GFP removes highly conserved sequences at the C-terminus (595 amino acids) (B) Live-cell imaging of full-length Fmp27-GFP and Fmp27 $\Delta$ C595-GFP with the ER marker RFP-HDEL shows that C-terminal truncation of Fmp27 reduces its localization to cortical ER. FMP27GFP and C-terminal truncation were made at the endogenous FMP27 locus and are expressed under the endogenous promoter; RFP-HDEL was expressed from a plasmid.

\section{A}

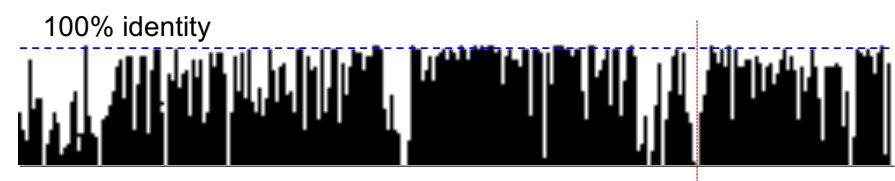

Fmp27 $\triangle$ C595-GFP

B

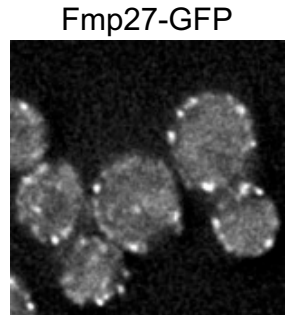

Fmp27 $\triangle$ C595-GFP

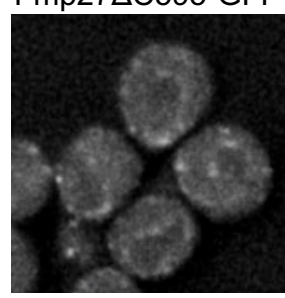

RFP-HDEL

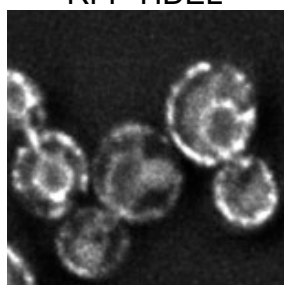

RFP-HDEL

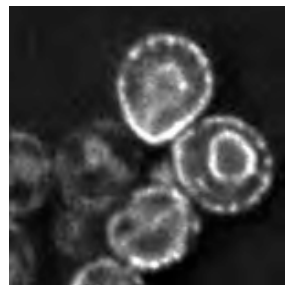


Movie 1. Imaging-based protease protection assay with full-length Hobbit-GFP. Live-cell time-lapse imaging of cytosolic mTagBFP2 (cyan), full-length Hobbit-GFP (green), and KDEL-RFP (red) in an imaging-based protease protection assay. The selective detergent digitonin, which permeabilizes the plasma membrane but not intracellular membranes, was added at timestamp $28.049430 \mathrm{~s}$, and proteinase $\mathrm{K}$ was added at timestamp 2 min $4.664132 \mathrm{~s}$. Still images from this time-lapse are pictured in Fig. 4C.

Movie 2. Imaging-based protease protection assay with Hobbit $\Delta$ C82-GFP. Live-cell time-lapse imaging of cytosolic mTagBFP2 (cyan), Hobbit $\triangle$ C82-GFP (green), and KDEL-RFP (red) in an imaging-based protease protection assay. The selective detergent digitonin, which permeabilizes the plasma membrane but not intracellular membranes, was added at timestamp 1 min $45.964512 \mathrm{~s}$, and proteinase $\mathrm{K}$ was added at timestamp 3 min 47.512041 s. Still images from this time-lapse are pictured in Fig. S3C. 